\title{
Gentlemanly Satisfaction: The Wellington-Winchilsea Duel of 1829
}

\section{by Bruce Dolphin}

When, in 1829, the Duke of Wellington's governmen moved to pass Roman Catholic emancipation-basically the restoration of the right of British and lrish Catholics to sit in parliament-Lord Winchilsea in Ultra-Tory outrage publicly and without parliameniary immunity accused the prime minister of having treacherousty plotted the destruction of the Protestani consititution. The resulting passage of arms in London's Battersea Fields, through its unusually abundant documentation, provides a singular moment of insight into not only the personal qualities of the participants, but also the political culture of the time and the decline of duelling in British society.

Lorsqu'en 1829, le gouvernement du Duc de Wellington fait voter la Loi d'émancipation des catholiques (qui rétablit le drait des catholiques irlandais ế anglais de siéger au Parlement), l'ultra-conservateur Lorä Winchilsea accuse, publiquement et sans immunité parlementaire, le premier ministre d'avoir trahi la constitution protestante el conspiré en vue de sa destruction. Le duel qui s'ensuit à Battersea Fields, à Londres, et sur lequel les documents sont étonnamment nombreux, est riche d'enseignements sur les qualités personnelles des protngonistes ainsi que sur la culture politique de l'époque et le déclin du duel dans la société britannique.

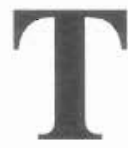

wo pistoi shots, with but a momentary interval, rent the quiet morning air of south Lendon's Battersea Fields, part of what was then still a Thames-side market garden suburb. It was shortly after 8 A.M., Saturday, 21 March 1829, and Arthur Wellesley,' Duke of Wellington and British Prime Minister, had just stood his ground with George Finch-Hatton," Earl of Winchilsea and Nottingham. The event constituted the second, and last, time that an incumbent first minister of the crown fought a duel, the previous such meeting having taken place not far to the west, on Putney Heath, where William Pitt faced George Tierney, M.P. for Southwark, in 1798. While these encounters are today obviously far removed from McGill in time, custom and geography, duelling was not uncommon in Canacia during both the French and British colonial regimes.

indeed, two of McGill College's original four facuity members, both Scottish-born British ar my veterans of the War of 1812 who became medical doctors, haci occasion to issue or accept a formal appcal to arms in civilian life. In 1819 Dr. William Caidwell exchanged fire five times in a tenacions combat with Michael O'Sullivan, M.L.A. for Huntingdon and future chief justice of Montreal, which each man surprisingly survived despite serious wounds. Thirteen years latcr
Dr. William Robertson, first head of the McGill Medical Department and a Montreal magistrate, challenged the Patriote leader Louis-Joseph Papineau. The duel did not come off, yet the intent was there on Robertson's side. ${ }^{3}$ But feisty physicians aside, the circumstances of the Wellington-Winchilsea contest find abundant primary source documentation - much of it difficult or impossible to obtain elsewhere - in the Hardinge Papers (MSS. 315) held by the Deparment of Rare Books and Special Collections, McGill University Libraries.

The foregoing papers record the career of Sir Henry (later Viscount) Hardinge, ${ }^{4}$ an individual not without some Montreal association in that, as a young officer in the Queen's Rangers stationed in the city, he drove off at sword-point a number of robbers assaulting Edward ("Bear") Ellice, a Scottish merchant. Some years thereafter Ellice returneci home to Britain where as a Whig politician he achieved ministerial tank. ${ }^{5}$ Most commonly remembered for his role in the 1840s as the British commander in the First Sikh War and as governor-general of India, Hardinge served as Wellington's second in the 1829 meeting with Winchilsea which engaged, as principals or seconds, four members of what was still ostensibly the same Tory governing party. In fact from the beginning the Wellington administration, formed in January 1828 , like 
other post-Napoleonic War governments faced divisions between the ministerial front bench and an Ultra-Tory, mostly back bench, right wing disgruntled by what it saw as the government's tendency to temporize in its support for the landed interest and, as the phrase went, "the Protestant constitution in church and state."

Ultra-Tory suspicions of ministerial unsteadiness-"... I shall begin to fear, that all is not well at Head Quarters, " 6 as one Ultra put it -gave way to anger and bitter feelings of betrayal when, early in 1829 , the administration announced its intention to pass the long passionately-debated measure commonly known as Roman Catholic emancipation. The divisive nature of the Catholic question had kept it an "open" one in cabinet since the advent of Lord Liverpool's ministry in 1812 but now, argued the Wellington government, conditions were critically altered. While other considerations were involved, the immediate rationale for this dramatic change in policy was to prevent the outbreak of another rebellion in Ireland on the scale of 1798 or even 1641 , augured by the recent massively successful agitation of Daniel O'Connell's Catholic Association in that country. In essence, Cathoilic emancipation meant the repeal of the Papist Disabling Act of 1678 passed as part of the constitutional and religious struggle culminating in the "Glorious Revolution" a decade later and the expulsion of the Catholic King James II. The Papist Disabling Act set criteria to be met by every member of the Lords and Commons before they took their seat. By 1829 , those loyal to Rome in the spiritual realm had long since reached a consensus that an equitably-worded oath of supremacy (i.e. allegiance) to a Protestant monarch in the temporal realm constituted no moral obstacle, but the required abjuration of the doctrine of iransubstantiation in holy communion proved another matter. While this anti-transubstantiation regulation stood, any conscientious Catholic, or indeed by the scruples of the time, virtually any nominal one, was thus de facto though not explicitly de jure barred from sitting in parliament.

Popular Protestantism drew upon an anti-Catholic iradition inspired by events - or a version of eventswhich began at least as far back as the church reform agitation of John Wycliffe, and was successively buttressed by the reign of Bloody s.r.y and the slightly later threat posed by the Spanish A rmada and (had the
Armada been successful) the Inquisition, on through Guy Fawkes and the Gunpowder Plot, the 17th century Civil Wars, the Titus Oates affair and the several Irish and Jacobite risings. In keeping with this spirit, the Ultra-Tories and their numerous supporters at large in Britain and Ireland-many of the more prominent of them members of Orange Lodges, Pitt Clubs, or Brunswick Constitutional Clubs-held that harsh historical lessons taught the necessity of an exclusively Protestant parliament for the preservation of national independence and constitutional liberties against the collective Catholic tendency to intolerance in religion, despotism in the state, and obscurantism in both. There also existed the closely related concern that the introduction of a large number of Catholic Irish parliamentarians would, to the peril of Ireland's Protestant population, greatly increase demand for the repeal of the 1800 Act of Union which united the British and Irish legislatures. But in any case, from the Ultras' perspective, their own position was a matter of patriotic prudence, not anachronistic anti-Catholic bigotry as claimed by critics who included some more liberal, or in other cases merely more religiously indifferent, Tories.?

With this, and Tory internecine parliamentary battles over Catholic emancipation, as background, Winchilsea addressed his Protestant countrymen by means of a public letter to Henry NcIson Coleridge in the London-based but nationally circulated Standard, ${ }^{8}$ the leading UItra-Tory daily newspaper edited by Stanley Lees Giffard, an Irish Oraigeman and LL.D. of Trinity College, Dublin. Winchilsea's declaration, written at his Eastwell Park estate near Ashford, Kent, was dated 14 March and published two days later. Thus began. a series of letters, notes, memoranda and negotiations which, while perhaps not without parallel in their punctilio, probably have never been equalled with respect to the fullness of their documentation of the proceedings attending a duel. Certainly it is doubtful that any other encounter of the kind in British history ever generated as many first-hand records, to which the Gardinge Papers make an important contribution.

In his open letter published in the Standard, Winchilsea accused his party chief, the prime minister, of having been a secret convert to the policy of Catholic emancipation since the previous year, when Wellington (on 21 June, though the exact date was not mentioned) 
presided at the inauguration of King's College, London, as a Christian (more specifically an Anglican) antidote to the agnostic University College promoted by many Radicals and the more "advanced" of their sometimes uneasy Whig allies. Inasmuch as Wellington used the occasion and his contribution to the King's College establishment fund to deceive others into thinking he was stiil a firm supporter of the existing constitution in church and state, ran the letter, Winchilsea as another contributor now felt compelied to remove his own name from the list of subscribers to a morally compromised enterprise.

\section{He further explained:}

...I confess that I felt rather doubtful as to the sincerity of the motives which had actuated some of the prime movers in this undertaking, when : considered that the noble Duke at the head of his Majesty's government had been induced, on this occasion, to assume a new character, and to step forward himself as the public advocate of religion and morality.

Late political events have convinced me that the whole transaction was intended as a blind to the Protestant and High Church party, that the noble Duke, who had for some time previous to that period determined upon 'breaking in upon the constitution of 1688,' might the more effectually, under the cloak of some outward show of zeal for the Protestant religion, carry on his insidious designs, for the infringement of our liberties, and the introduction of Popery into every department of the State. ${ }^{9}$

Regardless of libel laws, the conventions of extraparliamentary debate made allowances for strong language, and partisans could safely go quite far in attacking the opinions, attitudes, and even the intelligence, of opponents. However, something one could not do in the higher ranks of male society, without considerable probability of being called out to answer at the risk of one's life, was cast serious aspersions upon the personal character or honour of anyone deemed a "gentleman." Charges which threatened to go as far as those in the Standard were currently being made under parliamentary immunity by other Ultras, and indeed by the Earl himself, at Westminster. As recently as 12 March, Wellington's confidante Harriet Arbuthnot noted an harangue typical in both substance and style when she wrote that

Lord Winchilsea made a furious attack upon the Duke last night, called him despotic \& arbitrary, said he had deceived the people, called upon him to dissolve Parliament [for a general election] and ended by moving for a [statistical] return of all Catholic priests \& monks in the United Empire. L[or]d Winchilsea always speaks in the House of Lords as if he was shouting to a mob on a windy day upon Pennenden Heath. I never heard such a voice in my life. I went last night \& he had begun before I got there, and we actually heard him in the lobbies. ${ }^{10}$

So much for Westminster, but when Winchilsea (Fig. 1, see p. 93) impetuously came forward a few days later publicly in print, he no longer enjoyed parliamentary immunity. The Ultra-Tory Earl thus inadvertently presented the prime minister with the welcome opportunity for a political counter-attack which could be couched in terms of a defence of personal honour particularly telling with fellow peers in the Lords, where Ultra-Tory strength was greatest.

In this connection Wellington later revealingly reported to the Duke of Buckingham, a ministerial supporter whose son and heir, Lord Chandos, was a well known Ultra:

The truth is that the duel with Lord Winchilsea was as much part of the Roman Catholic question, and it was as necessary to undertake it and carry it to the extremity to which I did carry it, as it was to do everything else which I did to attain the object which $I$ had in view.

I was living here for some time in an atmosphere of calumny. I could do nothing that was not misrepresented as having some base purpose in view.

... The courts of justice were shui, and not to open till May. I knew that the Bill must pass or be lost before the 15th of April.

In this state of things Lord Winchilsea published his furious ietter. I immediately perceived the advantage it gave me; and I determined to act upon it in such a tone as would certainly put me in the right. Not only was I 
successful in the execution of my project, but the project itself produced the effect which I looked for and intended that it should produce .... The system of calumny was discontinued. Men were ashamed of repeating what had been told to them; and I have reason to believe, moreover, that intentions not short of criminal were given up in consequence of remonstrances from some of the most prudent of the party, who came forward in consequence of the duel.

I am afraid that the event itself shocked many good men. But I am ceriain that the public interesis at the moment required that $I$ should do what I did, $"$

The prime minister's aliusion to the law courts being closed implies that, had they been in session, he might have considered filing an ex officio action for libel. Such was the course soon to be adopted by Wellington against Robert Alexander, a Scot resident in London where he served as editor of the Ultra-Tory Morning Joumal. But political journalists were widely considered members of a disrepuiable pseudoprofession, hardly gentlemen socially fit to duel with aristocrats and peers of the realm. Winchilsea's status as a member of the House of Lords made him eminently challengeable, however, and the Duke opened his part of the proceedings the same day (Monday, 16 March) the offending ietter appeared in print.

in Loncion, he sent a brief note enquiring of Winchilsea whether the item in the Standard was written by the Earl and published by his authority. Wellington's note took two days to reach its intended recipient in Kent since it was first directed to Winchilsea's Suffolk Street house in the capital though the provocative newspaper piece bore an Eastwell Park address. By this time the Duke had despatched a duplicate of his original communication. ${ }^{12}$ Winchilsea, receiving both items, one early and one later, on Wednesday, 18 March, replied immediately: "My Lord-The inclosed is a copy of the answer which I retumed, by this day's post, to your Grace's letter, which oniy reached me this morning. I intend leaving this place for London to-morrow morning, and expect to be at No. 7, Suffolk-street, between four and five o'clock in the afternoon." $\mathrm{He}$ acknowledged responsibility for the letter in the Standard, adding that, "As I had publicly given my approbation and sanctios to the establishment of the King's College, London, lasi year, by his Grace the Duke of Wellington becoming a subscriber to it, I thought it incumbent upon me, in withdrawing my name, also publicly to state my reasons for so doing." 13

Though Monday's accusations against the Prime Minister caused a minor stir in political circles, little thought ensued as to the likelihood of "anything serious" in the way of consequences. Indeed when, on Wednesday, Privy Council Clerk Charles Grevilie asked Lord Bathurst, Lord President of the council, at Windsor Castle if he had read Winchilsea's deciamation, Bathurst jocularly replied, "Yes, and it is a very clever letter, much the wisest thing he ever did; he has got back his money. I wish I could find some such pretext to get back mine." 14 Nor was the Lord President's drollery the only example of humour, or at least of something amusing, manifested in an increasingly rancorous battle whose possibilities for personal danger few as yet properly appreciated.

The handkerchief incident of a short time previous derived not from the press, but from the House of Lords where, as might be expected, Winchilsea's reputation was that of the most impassioned speaker amongst its membership. Moreover, the Uittra-Tory Earl habitually accompanied his Protestant rhetoric at Westminster with flourishes of à white pocket handkerchief in a gesture of anything but surrender. Hence the understandable confusion of the Whig Lord Holland who was surprised when, arriving home one night after sitting near Winchilsea, he found himself in possession of a handkerchief bearing a monogrammed letter "W. "Holland duly forwarded the article, together with a complimentary note, to its even more surprised and confused supposed owner. Already on bad terms with Wellington, Winchilsea upon receipt of the handkerchief in turn "fancied it was the Duke's ... sent by way of affronting him, "15 as Greville records. It is significant that Winchiisea did not go personally, but rather chose a second party, his friend and fellow-Ultra Henry Pelham-Clinton, Duke of Newcastle, to visit Holland for an explanation-practice consistent with an attempt to clear up ambiguity as to whether a challenge had been intimated. Newcastle met Holiand, whereupon the cloud lifted when the mysterious handkerchief was discovered to belong not to the Prime Minister, but to Lord Wellesley, his older brother. Again according to 
the clerk of the privy council, "The next day Lord Winchilsea came up laughing to Lord Holland in the House of Lords, and said he had many apologies to make for what had passed, but that he really was in such a state of excitement he did not know what he said and did. ${ }^{n}$.6

Yet if the handkerchief affair ended lightheartedly, ii nonetheless quickly proved in its own way portentous. Anticipating events as he prepared to leave Eastwelt Park in response to Wellington's written enquiry, Winchilsea once more requested Newcastle to negotiate for him. But the letter, directed to Newcastle's London residence, gave rise to another insiance of delayed delivery since the Duke was out of town. In any case, while otherwise still very well disposed toward his Ultra ally, Winchilsea, Newcastle felt relieved to have escaped helping him on this occasion: "It was most fortunate for me that I was not [in London], for nothing that could have been required of me would have been more utterly distasteful...than io have acted as [a] second in a duel. " ${ }^{17}$ With Newcastle unavailable, Winchilsea immediately upon arrival in town about 4 P.M. next appealed to a Cornishman, Edward Boscawen, ${ }^{18}$ Earl of Falmouth, to perform what was to prove an emotionally exhausting, rather thankless task.

Taken by surprise, Falmouth remembered reading the recent letter in the Standard, but until approached by Winchilsea "knew nothing whatever" of the resulting correspondence and its ramifications. ${ }^{19}$ However, he agreed to act for a fellow Ultra. Wellington meanwhile enlisted his colleague Sir Henry Hardinge, the Secretary at War, as his second. With Winchilsea's return to London in the afternoon of Thursday, 19 March, the main players were in place. Only Hardinge had personal experience of such matters, having in 1824 served as a second for his brother-in-law, Lord Londonderry. As gentlemen, all understood the basics of the contemporary code duello and the need, at least as things stood in British society by the end of the third decade of the 19th century, for the utmost discretion, indeed secrecy, in arrangements. This arose in part from a desire to spare family and friends worry, but was also to avoid interference by them or others in an exercise of ritual violence regarded with increasing disfavour even in aristocratuc quarters. Legally, the potential existed for a situation politically embarrassing for Wellington and Hardinge in which all the participants could be arrested for a breach of the peace by any magistrate or Bow Street Runner who possessed reasonable evidence of intent, and was not over-awed at the thought of taking into custody the King's first minister as well as the Secretary at War together with two peers engaged in criminal conspiracy with them.

The secretive quartet certainly shared some significant social and political similarities. At the most basic level, all were Anglican and (which was by now essentially true of the Anglo-Irish Wellington aiso) English; and all were or, in the case of Hardinge, would be in due course, members of the peerage. Moreover, each was sufficiently politically partisan that they either had been, or would be within five years, awarded the accolade of an honorary Doctor of Civil Law degree from that historic spiritual home of Toryism, Oxford University. Yet at the same time, certain striking differences between the two sides in the projected proceedings present themselves. The nearly 60 year old Prime Minister, the "Great Captain" as he was popularly known (later to be also styled the "Iron Duke"), a major figure on the European political and military stage, had for much of British society long since acquired the status almost of a demigod, being awarded laurels and lands by parliament on a scale unprecedented since the rise a century earlier of John Churchill, Duke of Marlborough, another national soldier-hero. Hardinge, Wellington's trusied comradein-arms from the Peninsular and Waterloo campaigns, came from the gentry and hence a socially lower origin than the Duke, a younger son of the Earl of Mormington; but the Secretary at War had already achieved considerable public stature. Also, each man had much experience with violent death and injury gained during active military years. Wellington, despite all the carnage in which he had been a director, was lucky enough to have escaped with no more than a slight wound from a spent French bullet. (Fig. 2, sec p. 94) His second Hardinge (Fig. 3, see p. 95), however, was twice seriously injured during the Peninsular conflict, having been with Sir John Moore when he fell in action while in command at Corunna in 1809. Later, at the Battle of Quatre Bras, two days before Waterloo, Sir Henry lost his left hand. Thus, for the ministerial team, were professional soldicrs in politics. 
By contrast, their. Ultra counterparts were back benchers, and civilians. Falmouth was, in 1807-1808, an ensign in the Coldstream Guards, ${ }^{20}$ but he does not seem to have seen combat. Winchilsea, aged 38 in 1829 , a Deputy Lord Lieutenant for the County of Kent, had for 20 years held a captaincy in the Kent militia and, for a decade, the rank of Lieutenant in the Northamptonshire yeomanry. ${ }^{21}$ But he was at least as innocent of the violence of real military service as his second, the militia and the yeomanry, especially in peacetime, being more social clubs of convivial Saturday night amateur soldiers than effective formations of authentic ones. Both Winchilsea and Faimouth, as members of landed. society, certainly did some upland game shooting in season; but occasionally swinging a shotgun at grouse, pheasants and woodcock on the moors scarcely compared to years of military campaigning as conditioning for the deliberate shedding of human blood.

Again, the two Ultras as back benchers commanded incomparably less parliamentary and national prominence. This remained true although Winchilsea's stentorian orations in the Lords gained attention enhanced by well-reported addresses to Kentish public meetings in the autumn of 1828 . His successfully demagogic performance in these gatherings at Maidstone (to promote the Brunswick Club movement) and at nearby Pennenden Heath (the latter event a full-scale county meeting which carried a strongly Protestant resolution), reflected the sense of conviction he expressed shortly before. "I, for one, am determined," he told Chandos, "to remain no longer quiet, but to exert, to the utmost, the humble talents \& power which I possess, in raising the dormant spirit of the Country, \& awakening it to the perilous situation in which we now stand."22 Yet, some months later, Winchilsea's reckless language now stood him much more personally in a different, potentially fatal, "perilous situation." Obliged to rely heavily on Falmouth's agency, he faced the daunting prospect of dealing in a matter of mortal seriousness with one of the foremost figures of the age, at once a living national monument, Prime Minister, Field Marshal and party chief.

Though not without supporters at the popular level, Winchilsea's public posture invited ridicule and contempt: from government adherents, Catholics,
Whigs, Radicals and, in general, a heterogeneous array of reformers ranging from liberal Protestants and philanthropists to the fashionably ungodiy. Greville, learning of the duel shortly after it occurred, was perhaps especially' sarcastic in his reference to the Earl as: "such a maniac" who "has so lost his head;" 23 but he echoed a wider sentiment. Yet a month earlier a more charitable, and fairer, estimation was made: by' the Whig Lady Holland: "Some of the [Ulira-Tory] Lords are really de bonne foi, such as Lord Winchilsea, who is not a very able man, but who is honest., frank, and zealous in what he thinks the duty of a true Protestant. I. like him personally for his warmth, and sincerity. "24 In essentially similar terms Roundell Palmer (later the Liberal Lord Selborne, and lord chancellor), who not only knew Winchilsea but as a youth lived for a time as a tutor to his eldest son in the household at Eastwell Park, spoke of his host as "a man of trank, kindly", and generous character, but not wise." Palmer added that it would have been better had the Ear! been guided more by Lady Winchilsea (a daughter of the Scottish Duke of Montrose), for she possessed. a. better sense of practical political discretion than did her husband. ${ }^{25}$ Thus, in part, for the character of the Duke"s verbal assailant.

Intent on orchestrating developments (and on publishing their course if and whert warranted.) according to the dictates of political policy, Wellington understandably wanted to ensure the exactness of his own records. "I shall be very much obliged to you if you will send me back the Letter for a Moment; as I don't think that the Copy which I have kept of it is accurate. You shall have it back directly, "26 he wrote to Hardinge, whom he also requested to deliver the following communication to Winchilsea:

London, March 19, 1829.

My Lord - I have had the honour of receiving your Lordship's letters of the 18 th instant.

Your Lordship is certainly the best judge of the mode to be adopted of withdrawing your name from the list of subscribers to the King's College.

In doing so, however, it does not appear necessary to impute to me, in no measured terms, disgraceful and criminal motives for my conduct in the part which I took in the establishment of the College.

No man has a right, whether in public or in 
private, by speech or in writing, or in print, to insult another by attributing to him motives for his conduct, public or private, which disgrace or criminate him.

If a Gentieman commits such an act indiscreetly, in the heat of debate, or in a moment of party violence, he is always ready to make reparation to him whom he may thus have injured.

I am convinced that your Lordship will, upon reflection, be anxious to relieve yourself from the pain of having thus insulted a man who never injured or offended you.

$$
\begin{aligned}
& \text { I have, \&c... } \\
& \text { Wellington }
\end{aligned}
$$

Sir Henry found Winchilsea in the late afternoon or early evening, gave him the letter, and was duly referred to Falmouth as Winchilsea's representative.

Perhaps as long as several hours elapsed before the Secretary at War met Falmouth and the two men began negotiations in earnest. Falmouth presented Winchilsea's reply, in the form of a memorandum, to the Duke's request for "reparation" made earlier in the day. ${ }^{28}$ Winchilsea averred that,

Whether I may determine to give an explanation of my letter published in the Standard. on Monday last, will depend upon the correctness of my belief that I had grounds for the opinions complained of by the Noble Duke ....

I. am ready to allow that I was mistaken in my view of the Noble Duke's conduct, as expressed in my public letter to $\mathrm{Mr}$. Coleridge ... and to state my regret at having so expressed it, provided that the Noble Duke will state on his part that at the time he came forward to preside at the meeting for the establishment of King's College, London, he did not contemplate the measures which are now in progress for Roman Catholic Emancipation-or, to use Mr. [Robert] Peel's words, 'for breaking in upon the Constitution of 1688'; but without some statement to that effect from the Noble Duke, I cannot withdraw the expressions contained in the above letter: ${ }^{29}$

After some talk, Hardinge left to convey this answer to Wellington, but returned at midnight. In the course of these discussions, when asked "the extent of reparation that would be expected, "Hardinge suggested. two alternatives that amounted to the same thing: Winchilsea should either write another letter to Coleridge, or one to the Duke himself, expressing regret at having wrongly attributed highiy offensive motives to Wellington in the King's College enterprise -this for publication in the Standard as the original organ of record. Falmouth, on Winchilsea's behalf, objected to the words "Which motives he is now sensible he was not justified in imputing to his Grace" in a proposed amend, ${ }^{30}$ presumably since it still avoided the issue of whether Wellington had indeed, as charged, decided upon Catholic emancipation at the time in question. There things rested between the parties who agreed to meet again after a few hours sleep on what was already Friday, 20 March.

But Falmouth, aithough feeling the pressure of the circumstances into which he had been so unexpectedly thrust, reported yet again in person back to Winchilsea before finally retiring for the night. It is the more understanciable, therefore, that next morning with, as events were to unfold, almost exactiy 24 hours to go before the moment of truth, Falmouth hurriedly despatched the following note to Sir Henry. "I did not get to bed tili past two this morning-\& have overslept myself after having run about so much from four o'clock yesterday to that hour, "he explained. "Anxious io prevent extremities if I can properly do so I will with your concurrence make one more attempt before I. acquaint you with the result of my one o'clock visit last night, when fatigue had made me very unfit for stach business, \& I will afterwards be with you as soon as l. can at the War Office-I hope before ten o'clock. "3!

While Falmouth experienced the vicissitudes of being a second, Wellington responded to the previous day's memorandum from Winchilsea with one of his own. "I may lament," he commented, "that a Nobleman for whom I. feel the highest respect, entertains a bad opinion of me. But I don't complain as long as that opinion is not brought before me." He then proceeded to say,

[However] I cannot admit that any man has a right to call me before him to justify myself from the charges which his fancy may suggest. 
That of which I complain is, that the Earl of Winchilsea and Nottingham should have published an opinion that I was actuated by disgraceful and criminal motives in a certain transaction that took place nearly a year ago.

His Lordship, unprovoked, has insulted me by stating in writing, and authorising the publication of this opinion. For this insult I believed, and am not willing to part with the belief, that his Lordship will be anxious to give me reparation. ${ }^{32}$

This document merely repeated the gravamen of the Prime Minister's previous letter. And again, it did not address the Ultra Earl's contention about the chronology of the intention to carry Catholic emancipation. Consistent with this, in a related memorandum Hardinge stated that a disclaimer by Wellington as to "having contemplated the intentions attributed" to him, was "as a preliminary to any explanation. [by Winchilsea] ... inadmissible. ${ }^{133}$

Falmouth wrote, and Winchilsea signed, the Ultra message in return:

March 20, One o'Clock.

Out of respect for the Duke of Wellington, Lord Falmouth has taken to Lord Winchilsea the Duke of Wellington's Memorandum, put into his hands by Sir Henry Hardinge, this morning, at the War-office, with Sir Henry's own note thereon.

In reply, Lord Winchilsea does not feei himself in a situation to comply with the expectation therein expressed, as to the withdrawal of his public letter. Lord Winchilsea, therefore, desires that Lord Falmouth will decline doing so on his (Lord W.'s) behalf.

$$
\text { Winchilsea. }{ }^{34}
$$

In view of the impasse, after Falmouth delivered this note to his opposite number a "calling out" might be anticipated at any moment. Nonetheless, Hardinge wrote at 2 P.M. saying, "I feel it to be my duty, before I make a final communication to your Lordship, to ascertain beyond the possibility of a doubt, that Lord Winchilsea declines to give the reparation which the Duke of Wellington considers himself entitled to receive." At 3:30 Falmouth found himself unable to do more as a rejoinder than refer the Secretary at War to the one o'clock item bearing Winchilsea's signature, somewhat repetitiously adding "that if by the word 'reparation' any withdrawal of Lord Winchilsea's public letter, or expression of regret for its contents, be expected, he does not feel himself to be in a situation to comply with such expectation. ${ }^{135}$

Before 5 P.M. Falmouth and Sir Henry met, verbaily agreeing that the encounter between their principals would take place at 8 o'clock the next morning in Battersea. Fields, a location both convenient and reasonably secluded. Only after this, at $6: 30$, did Wellington personally issue a formal challenge:

Since the insult, unprovoked on my part, and not denied by your Lordship, I have done everything in my power to induce your Lordship to make me reparation-but in vain. Instead of apologising for your own conduct your Lordship has called upon me to explain mine.

The question for me now to decide is this-Is a Gentleman, who happens to be the King's Minister, to submit to be insulted by any Gentleman who thinks proper to attribute to him disgraceful or criminal motives for his conduct as an individual. I cannot doubt of the decision. which I ought to make on this question. Your Lordship is alone responsible for the consequences.

I now call. upon your Lorđship to give me that satisfaction for your conduct which a Gentleman has a right to require, and which a Gentleman never refuses to give. ${ }^{36}$

Enclosed with a covering letter from Hardinge, the envelope reached Falmouth shortly after $80^{\circ}$ clock when he "had just sat down to dinner, and being in company ... could not read it without exciting suspicion. till some time afterwards." The Earl next found Winchilsea and delivered Wellington's note. Since things had already been arranged by the seconds some hours earlier, Falmouth either naively or, perhaps, already with a hint of suspicion, ventured to Hardinge the presumption that the Duke's apparentiy superfluous written challenge "was meant merely as a customary form on such occasions. ${ }^{37}$ But it is unlikely that he as yet appreciated the extent to which, for the Prime Minister, the affair was really an instrument of politics and not a function of individual honour, hence the need for documentation: (including that of the actual calling out) to be subsequentily published. 
Hardinge the same evening contacted his own friend and Wellington's personal physiçian, Dr. John Robert Hume, to be in attendance at the intended event. Hume's eldest daughter, Elizabeth, and Lord Douro, the Duke's eldest son, both in their eariy twenties, had for some years been spoken of as a possible match, Douro certainly at times expressing a romantic interest in the young lady. Yet with an engagement of quite another sort on his mind, it was not a daughter-in-law which Wellington immediately required of the doctor but, somewhat incongruously, both medical skill and weapons to inflict damage to test such skill-neither the Prime Minister nor his second owned duelling pistols, which they therefore borrowed from Hume. ${ }^{38}$ To maintain security, the summons was so circumspect that, while its recipient could hardly fail to discern the nature of the occasion that was in the offing, no mention was made of the parties, place or time, except that the physician should be at the Secretary at War's house no later than 6:45 the next morning. Ironically, a very alarmed Hume assumed that his correspondent, Sir Henry, was one of the principals, and confessed himiself "almost tempted, instead of answering it, to carry your note to the Duke immediately," so that Wellington could intervene to save Hardinge from danger. But, trusting to Hardinge's "good sense," he agreed despite misgivings to serve as requested..$^{39}$

It now remained only for the challenged party to send an answer, which was not long in coming:

\section{Suffolk-street, Friday Night, 11 p.m.}

My Lord-I have the honour to acknowledge the receipt of your Grace's note.

I have already had occasion to communicate to your Grace, that under existing circumstances, I did not feel myself in a situation to comply with what was required of me in regard to my public letter.

The satisfaction which your Grace has demanded, it is of course impossible for me to decline.

I have the honour to be, your Grace's most $o b[$ edien]t humble serv[an]t

Winchilisea. ${ }^{40}$

Hence, without the actual word "duel" evident anywhere in the extensive surviving preliminary correspondence and memoranda, all awaited the morrow.
Hume (with, presumably, a bag of first aid supplies as well as a brace of pistols) arrived at Hardinge's house in. Whitehall Place at the appointed early hour next day. ${ }^{41}$ There he learned of Sir Henry's role as a second in an imminent contest between "persons of rank \& consequence," but for the moment nothing more as to their identities. The doctor recounted later, however, that the Secretary at War "begged. of me particularly to keep near him on the ground that I might witness everything that took place, $\&$ be able to testify how anxious he had been to prevent this meeting \& what his efforts still were to avoid bloodshed." After receiving these tendentious instructions, Hume was sent off in Hardinge's carriage with only the coachman knowing the intended destination. The vehicle's owner meanwhile departed on horseback to "find his friend," the principal. The carriage went through Green Park, then by Pimlico, along King's Road, Chelsea, and crossed Battersea Bridge to the south bank of the Thames. It continued for approximately another half mile, stopping where two roads met at the base of a hill not far from a farm house,

Soon after he alighted, an astonished Hume found Wellington riding up to him in company with Hardinge. "Well, I dare say you little expected it was I who wanted you to be here," said the Duke with a laugh, upon which the doctor only with some effort to regain his composure managed to reply, "Indeed, my Lord, you are certainly the last person in the world I should have expected here. "Turning more serious, Wellington answered, "Ah! perhaps so-but it was impossible to avoid it, \& you will see by \& by that I had no alternative, \& could not have acted otherwise than I have done." As directed, Hume removed the pistols he had brought with him from their case, and walked after his two still mounted companions along the crossroad to the left, carrying the weapons under his greatcoat for conceaiment. Presently, after Wellington and Sir Henry twice rode up to higher ground to look for the other party and Hume hid the guns behind a hedge, Faimouth. and the other principal approached on foot from the road, having just arrived via Putney Bridge in a coach and four with armament of their own. The Duke and the Secretary at War dismounted; and the latter, approaching the newcomers with Hume, saluted while Wellington stood off at a distance. 
With all parties present, expedition was of the essence. Hardinge the soldier took the initiative and played the dominant role, especially as compared to his defensive and distraught opposite number. At the start, Falmouth did not help his own cause when he attempted. to apologise for being a little late because the coachman. had driven by way of Putney instead of Battersea Bridge. Nor did things improve when, twice in the next several minutes, he rather plaintively asked if a "paper" - a few hours later revealed as a sealed letter earlier that morning personally handed by him to Wellington's second, ${ }^{42}$ addressed with the words "To be read by Sir Henry after the affair shall have terminated ${ }^{43}$ - had been read, which gave Hardinge opportunities to curtly inform him, with animadversions about which side was responsible for matters coming to this point, that the note had indeed not been read. (In not yet having perused it, Sir Henry was after all only following the other party's written instructions, but it is indicative of the stress under which Falmouth laboured that the latter made these premature and awkward enquiries when he himself, of all people, must have been aware of the proviso in the paper's address).

The first field inte which the quintet turned proved to have some labourers at work in it. This necessitated leaping over a ditch to a neighbouring field which seemed to offer less chance of unwelcome scrutiny or interruption. Hardinge then presented his party's two pistols for inspection by Winchilsea's second, after which Hume, because the Secretary at War had only one hand, loaded the first weapon. He began loading the other, when Falmouth asked, "Will not one be sufficient?" Plainly he did not anticipate any need for more than one exchange of fire; but Hume, replying that he thought "it might save trouble afterwards," loaded the extra gun also. Hume had turned away when Falmouth called him back to watch the way in which he loaded for Winchilsea. The doctor at first answered carelessly, "You may load, my Lord, in any manner you please," but returned and offered to do it for him upon realizing that Falmouth, "a good deal agitated, "was shaking so much he seemed to lack the manual dexterity required to properly charge and prime a flintlock muzzle-loading single-shot weapon. However, loading only one piece rather than the two on the other side, Winchilsea's second managed to complete the task himself.
In the blufi yei controlled manner not uncharacteristic of him, the Duke began to show some. impatience. "Now then, Hardinge, look sharp and step out the ground. I have no time to waste. " 44 Sir Henry fixed the spot for his principal to stand with words of easy familiarity permitted an old friend: "Have the goodness to place yourself here, Duke." Falmouth preferred 18 paces but Hardinge, who insisted on 12 , prevailed, ${ }^{45}$ and in the end his counterpart merely confirmed the distance between the combatants. Winchilsea objected at first to being placed between two trees; his adversary cavilied for another reason- - "Damn it! don't stick him up so near the ditch. If I hit him he will tumble in, "46 Wellington cautioned. Hardinge. To shoot Winchilsea was one thing; to have him fall into a ditch would be quite another, and just not done.

With the duellists' positions satisfactorily adjusted, Hardinge stcod half way between them. He look a paper of his own from his pocket and called on Falmouth to approach near him, enjoining Winchilsea to Jisten also. The Secretary at War then admonished the two Uitras as being alone answerable for the possible consequences of what was about to occur, for good measure adding his prepared protest note as a peroration:

\section{My' Lord Falmouth}

I shall enter my Protest against this meeting by stating my' opinion on the ground, that as a Settlement of an affair of Honor, it is the most unnecessary to have forced to this point of any I ever heard of- $-\&$, that if I do not express my opinion to your Lordship in the same terms of Disgust as I Fave in the course of the affair, it is because I wish to adhere: to the line of moderation adopted by the Duke of Wellington. ${ }^{47}$

As Sir Herbert Maxwell, rightly observes in his biography of the Duke, since Hardinge represented the challenger, "remonstrance at this stage on his part was not a. little anomalous" according to etiquette in such matters. ${ }^{48}$

Winchilsea listened to this protest-eum-lecture with. apparent equanimity but, after Sir Henry finished, "said something in a low voice" to Falmouth of which Hume could only hear the words "rather sirong tanguage. "Winchilsea's second, though, was by now 


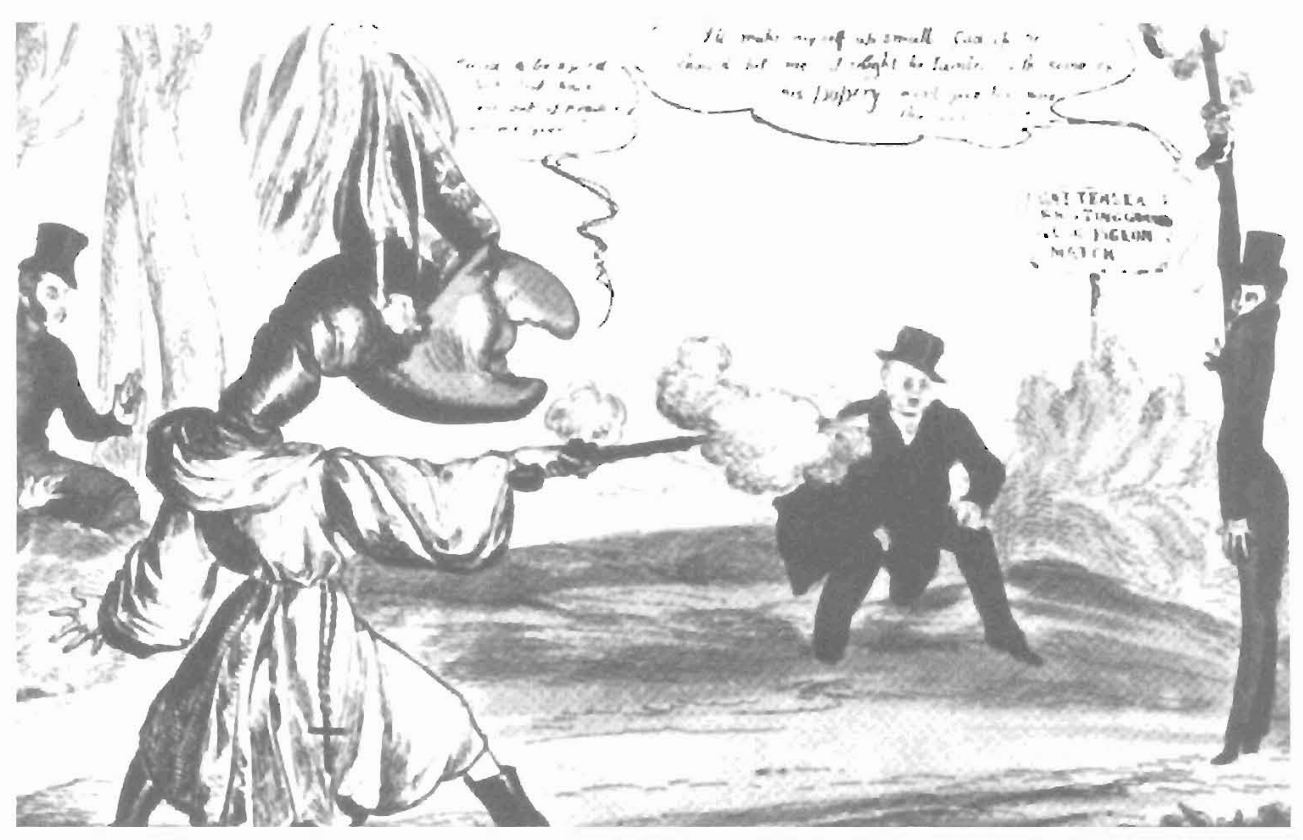

Figure 4. The Wellington-Winchilsea Duel. Drawing by W. Heath, published by Thomas McLean, 1829. Reproduced from The Duel: A History of Duelling by Robert Baldick. London: Chapman Hall, 1925, p. 104-105.

on the verge of breaking down. The doctor thought he saw tears in Falmouth's eyes as the man expressed the pain caused by the course he found himself obliged to pursue. In so doing, Falmouth moreover for the first time made the, in the circumstances, remarkable confession that he thoroughly disapproved of the publication of his principal's provocative, indeed "indefensible," letter. But in acting as a second he still maintained that "what he had done was unavoidable \& that when everything was over, he was confident even Sir Henry Hardinge would do him justice." Far from being moved by this, or by another query about the as yet unread "paper" given him, Hardinge merely coolly commented, as Hume remembered, "indeed, my Lord Falmouth, I do not envy you your feelings." Pointing to a group of on-lookers already gathered at the end of the field, the Secretary at War continued, "We had better take our ground; the sooner this affair is over the better."

At this the two men were given their weapons which, after cocking, they held in their right hands, arms extended down by their sides. Falmouth deferred to his opposite number: "Sir Henry Hardinge, I leave it entirely to you to arrange the manner of firing. "The Duke's second accordingly gave his directions, saying, "Then, gentlemen, I shall ask you if you are ready \& give the word 'fire' without any further signal or preparation." Following this the command came: "Gentlemen, are you ready? Fire!" Wellington instantly raised his pistol but, as Hume testifies, "observing that Lord Winchilsea did not immediately present at him, he seemed to hesitate for a moment \& then fired without effect." His opponent, whose arm had remained down at his side, "steady \& fearless ... received the Duke's fire, without making the slightest movement or betraying any emotion." Then, as Winchilsea deliberately raised his arm to the perpendicular and discharged his own gun in the air, Hume thought he saw a smile play over the man's features, "as if to say, 'Now you see I am not quite so bad as you thought me." (Fig. 4)

Wellington remained stationary, but Winchilsea and his second at this point approached Hardinge. Falmouth declared that, having stood his adversary's fire, his principal now felt at liberty to make the reparation required by the Duke. Winchilsea's second 
then drew from his pocket a written paper which he contended fully satisfied the purpose. Discussion with Sir Henry followed, during which Wellington drew nearer and. "listening attentively said in a low voice: 'This won't do. It is no apology.' " Hardinge walked off a short distance with the Duke, almost immediately returning to say, "I cannot accept of this paper unless the word 'apology' be inserted," whereupon the Secretary at War proffered yet another prepared paper of his own with the comment, "This is what we expect." Falmouth countered-rather evasively, in Hardinge's opinion ${ }^{49}$ - with the assurance that what he had written was meant as an apology in conformity with the terms of Wellington's memorandum of the previous day. But Sir Henry would have none of this, stating "My Lord Falmouth, it is needless to prolong this discussion. Unless the word 'apology' be inserted we must resume our ground. "Turning then to Winchilsea, whom Falmouth had momentarily called aside to converse with, he reminded him, "My Lord Winchilsea, this is an affair between the seconds," upon which Welinington's opponent dutifully withdrew.

Fortunately Hume now ignored any punctilio about negotiations being the monopoly of the seconds, and when after some hesitation a perplexed Falmouth appealed to him, he prevailed upon the Earl to add the contentious term. "Well, Sir Henry," Winchilsea's representative accordingly announced, "I will do it this way, \& I trust that will answer every purpose: I will insert [in] apology here in this manner" he went on, pencilling the phrase in the following rather convoluted text:

Having given the Duke of Weilington the usual satisfaction for the affront he conceived himself to have received from me, through my public letter of Monday last, and having thus placed myself in a different situation from that in which II stood when his Grace communicated with me, through Sir Henry Hardinge and Lord Falmouth, on the subject of that letter, before the meeting took piace, I do not now hesitate to declare, of my own accord, that, in apology, I regret having unadvisedly published an opinion which the Noble Duke states, in his Memorandum of yesterday, to have charged him with disgraceful and criminal motives in a certain transaction which took place nearly a year ago. I also declare, that It shall cause this expression of regret to be inserted in the Standard newspaper, as the same channel through which the letter in question was given to the public ${ }^{50}$

Hardinge and his principal, deeming this reparation adequate, prepared to depart without delay, buit the Secretary at War could not resist some verbal parting shots. "And now, gentleman, without making any invidious reflections, I cannot help remarking that, whether wisely or unwisely the world will judge, you have been the cause of bringing this man," said Sir Henry, pointing to the Duke, "into the field, where, during the whole course of a long military life, he never was before on an occasion of this nature." This wrung from the forlorn Falmouth yet another attempt at self-justification in which he repeated his disapproval, from the outset, of Winchilsea's iransgression. Hardinge remained unsympathetic, stating, in Hume's paraphrase, that if Winchilsea's second "did so [disapprove] and came with the writer of the letter to the ground, his Lordship had done that which he (Sir Henry) would not do for the dearest friend he had in the world." After this rebuff, Falmouth addressed the Duke who, bowing coldly to the two Ultras, had drawn near. But this effort to vindicate himself and explain the pain and anxiety he had suffered also met short shrift. Wellington, lifting up his hands, dismissed the entreaty brusquely - "My Lord Falmouth, I have nothing to say to these matters. "He touched the brim of his hat with a "Good morning, my Lord Falmouth; good morning, my Lord Winchilsea," at which point he and his companion mounted their horses and rode off as Sir Henry delivered a final. "I wish you good moming, my Lords."

At Falmouth's request, Hune in Hardinge's stead witnessed the Winchilsea paper, putting his own initials at the inserted "in apology" and his signature at the top and bottom of the document. Therr, as the men walked from the field back to their carriages, conversation continued, especially between the doctor and Winchilsea's voluble second. The latter, Hume remembered, "repeated again \& again how painful it had been to his feelings to be engaged in a business of this kind with a person for whom all the world and he \& Lord Winchilsea in particular entertained so much respect \& esteem as the Duke of Wellington." Putting his own polemical construction on events when he 
asked "then why did you push it so far?" Hume received from his complaisant interlocutor the reply that "it was impossible to avoid" because Winchilsea, being so much in the wrong, "could not have made any apology sufficiently adequate to the offence, consistently with his character as a man of honour, without first receiving the Duke's fire."

Wellington's physician countered with the argument that conduct justifiable or even admirable "towards an ordinary adversary, " could not properly be appiied to the duke. He followed this with an encomium about the latter, purportedly intended for his Ultra companions, whose artificial style strongly suggests it was subsequently touched up to maximize flattery in the written version given to the Duchess:

... I am filled with something approaching to horror, when, after exposing himself for so many years in fighting the battles of his country, after triumphing over all her enemies by a series of victories the most glorious \& complete that ever adorned the page of history, I see, he may still be forced to put himself on a level with other men \& expose to impertinence that life which he has so often risked for the benefit of us all. ${ }^{51}$

Falmouth's answer, the gist of which could probably be anticipated by this point, was that, "On this occasion at least he did not risk his life. I asșure you most solemnly, Sir, that on no other condition would I have accompanied Lord Winchilsea, except upon that of his acting in the manner he has done, \& his declaring to me upon his honour that he would not return the Duke's fire." Shortly thereafter, as the men neared the carriages, Hume observed that the circumstances which drew Wellington to the field were "all owing to that cursed spirit of party, which now, as in all times, obscures the judgement and destroys the better sympathies of your hearts." This elicited from Winchilsea, "as if speaking to himself," the reply "God forbid that I should ever lift my hand against him." Yet Winchilsea apparently stili showed some antagonistic spirit when he proceeded with, as Hume guardedly put it, "some remarks on Sir Henry Hardinge's manner of conducting the correspondence. ${ }^{n 2}$ These remarks, likely in line with the Earl's "rather strong language" comment about Hardinge's protest just before the duel, got only the aforementioned brief allusion from the doctor who either did not more fully recollect them or, not wishing to encourage bad. feeling, thought it best not to emphasize the matter in his narrative. But Hume was candid enough to quote Winchilsea's words of a moment later, "One thing, if I had taken as deliberate an aim at the Duke of Wellington as he did at me I should not have missed him." At this the doctor himself exclaimed, "Good God, Sir, how can you say the Duke took any deliberate aim at you! Did you not perceive that he hesitated from your not raising your pistol and presenting at him? I thought at one time he was going to take down his also, \& when it went off I scarcely think the muzzle was directed towards you."

The sound of the gunshots had hardly died away, therefore, when disagreement began as to whether Wellington intended to hit his antagonist, or deliberately missed hirn. Winchilsea remained firm in the conviction, Roundell Palmer recalled, that "he felt the wind of the Duke's bullet (as he himself told me) unpleasantly close to the curls of his hair," while Wellington is on record as informing his clergyman biographer, George Robert Gleig, that, seeing Winchilsea did not raise his gun, "I turned my pistol aside, and fired wide of him. ${ }^{\text {"53 }}$ This testimony derives from years after the event, but the contemporary evidence of both Hardinge and Harriet Arbuthnot, two of the duke's very few real intimates, matter-of-factly states that he "fired at" Winchilsea. ${ }^{54}$ On the other hand, Wellington's cabinet colleague Lord Ellenborough (president of the board of control; and, like Hardinge, a future governor-general of India) (Fig. 5, see p. 96) went further: "The Duke said he considered all the morning whether he should fire ai him or no. He thought if he killed him he should be tried, and confined until he was tried, which he did not like, so he determined to fire at his legs. He did hit his coat. ":55 Wellington did not hit Winchilsea's coat, and the assertion that he did is undoubtedly a rumour subsequentily interpolated; but there is nothing implausible in the rest of Ellenborough's account above.

The Duke usually made a poor showing with a shotgun, at times one dangerous to bystanders, having in the previous decade inadvertently hit with birdshot a dog; the legs of a gamekeeper; the arms of a woman hanging laundry out to dry; and his host, Lord Granville, in the face, the pellets luckily missing his 
eyes. Ineptitude with a shotgun did not necessarily translate into equal unskillfulness with a handgun, but accuracy with the flintlock duelling pistols of the day required much practice, and this Wellington manifestly lacked. Hence, whether he intended to shoot his opponent in a leg or anywhere else, or swing wide of him by a safe margin, it is alike more than possible that the miss was the close one Winchilsea claimed.

Wellington obviously fired at least in the general direction of the Earl. Winchilsea's magnanimous discharge of his own weapon in the air never aroused much controversy, yet neither this gesture nor his related. desire to end the confrontation at that point entirely escaped criticism. John Cam Hobhouse (the former boon companion of Lord Byron, current Radical M.P. for Westminster, and future Lord Broughton) was precious enough to recollect, speaking generally, "I believe that it was not reckoned fair for the person accused [i.e., challenged] to terminate the duel before he had exposed himself to two shots." However, Hobhouse gave the thought more personal application the Monday following the occurrence at Battersea Fields when, in conversation, he not only agreed with Speaker of the Commons Charles Manners-Sutton (after 1835, Lord Canterbury) that Winchilsea "had no right to fire in the air" and "ought to have received the Duke's second fire," but rather superciliously allowed as how, "after standing the two shots, I would nor have retracted," "56 Hobhouse might, of course, really have done this had the occasion arisen, thereby perhaps forcing exchanges to continue until death or injury ended the affair. Yet he was never in a duel-still less in Winchilsea's predicament facing an opponent of unique renown-and the M.P. for Westminster's bravado from the safeiy of the sidelines cannot be taken very seriously.

Those actually involved in affairs of honoun commoniy pragmatically modified or apparentiy simply ignored the stern, meticulous canons of the Clonmel Code and its $\mathrm{ilk}^{57}$ which, if of course with no legal sanction, were supposed to govern their conduct. Hobhouse's and Manners-Sutton's facile attitude notwithstanding, many precedents existed for Winchilsea's decision, including two of the most famous duels of the previous several decades. Prime Minister William Pitt bloodlessly closed his Putney Heath meeting with George Tierney by shooting in the air, admittedly on the second exchange. But fatality attended a Scottish attempt in 1822 when, at Auchtertool, Fifeshire, Sir Alexander Boswell of Auchinleck (son of James Boswell, the biographer of Samuel Johnson) fell mortally wounded trying to fire in the air on the first exchange with James Stuart of Duncarn. Sparing one's opponent was not without risk: neither was killing him, for while Stuart found himself acoultted after standing trial for murder in the high court of justiciary in Edinburgh, not all duellist defendants fared so well.

After leaving his own encounter, Wellington made no attempt to visit his semi-estranged wife, the Duchess, resident at the Stratfield Saye estate in Hampshire purchased for him by parliament in gratitude for his military victories, especially Waterloo. Rather, he repaired directly to an astonished Harriet Arbuthnot, walking in during breakfast with a jaunty "Well, what do you think of a gentleman who has been fighting a duel! " Arbuthnot's reaction, described to their mutual friend Lady Shelley, was understandable: "I am very glad I had no suspicion, for I should have died of fright .... The Duke ... seemed to think it an excellent joke, but I was ready to cry." 58 About noon, as part of his on-going campaign to keep the King from backing away from a most reluctant acquiescence in Catholic emancipation, the Prime Minister went to Windsor. There he persuaded George IV to agree to the dismissal of Attorney-General Sir Charles Wetherell (one of the few office-holding Ultra-Tories), for his vehement attacks on the administration. Wellington also informed the petulant but impressionable monarch of the duel, showing him Winchilsea's Standard letier. The King responded surpisingly positively: he approved of Wellington's conduct, going so far as to say that, had he seen the letter earlier, he would himself have called the Prime Minister's attention to it. Returning to London, the Duke that evening dined. with Harriet Arbuthnot and her husband Charles "in high spirits \& seemed rather pleased at having had a fight. ${ }^{59}$ For Wellington, Saturday constituted a good day's work.

Meanwhile others were also busy. Hume, doubtless back home on Curzon. Street, plunged into the report to the Duchess. At the same time cane a briefly renewed flurry of notes, which kept the messengers on the move between Winchilsea and Falmouth on one side, and the Secretary at War on the other. These 
centred upon the sealed letter received by Hardinge from Falmouth earlier that morning which stipulated it was "To be read by Sir Henry after the affair shall have terminated." Hardinge had by now, as instructed, read the document whose contents were as follows:

\section{Suffolk St[reet] \\ Friday night \\ March 20th 1829}

\section{My Dear Falmouth}

I. cannot hesitate to declare as I now do, that you had no knowledge whatever of my public letter of Monday last, until you saw it in the Newspaper, \& that you had no knowledge of my unfortunate affair with the D[uke] of Wellington, till I called upon you yesterday at four in the afternoon. I also wish to add that it is my determination not to fire at the Duke but after the first fire I shall offer the expression of regret, which I shall then be ready to make.

Of this I know you will approve for you have told me so. I own I have been wrong as you have told me in publishing the letter-but after having done so, to have with-drawn it or apologyzed in the manner proposed by Sir H[enry] Hardinge, without having grounds for believing my opinions to be incorrect, might have subjected me to imputations which would have made Life to me utterly worthless.

\section{Believe me My D[ea]r Falmouth \\ Ever Y[ou]r sincere \& obliged f[rien]d Winchilsea. ${ }^{60}$}

Writing Falmouth to request the "in apology" paper agreed upon at the scene of the duel, the Secretary at War took the opportunity to return the above "after the affair shall have terminated. letter by Winchilsea. While remaining coolly dismissive, Sir Henry nonetheless played the peacemaker in his own way: "The opinions of Lord W[inchilsea] in a private note to y[ou]r Lordship are not considered as having any thing to do with the transaction which has just terminated; - and if they had, I cannot for an instant conceive that y[ou]r Lordship could mean me to present the concluding part of Lord Winchilsea's note to the Duke of Wellington. At any rate I decline to do so. ${ }^{\text {"61. }}$ To have apprised the Duke of Winchilsea's "without having grounds for believing my opinions to be incorrect" stance would only have revived an issue whose dangers were obvious and, while Falmouth wanted Hardinge to clearly understand the terms of engagenent under which the Ultra side had acted, he was content to leave matters there.

I am honored by your note: returning Lord Winchilsea's letter to me, which letter I puí into your hands before the parties took their ground this morning. It thought it due to myself as weil as to Lord Winchilsea to make you acquainted with that letter, \& if any thing had happened to Lord Winchilsea it would have been a surviving testimony of the intention which he realised on the ground not to fire at the Duke: as well as of my conduct. You will of course exercise your own discretion as to acquainting the Duke with its contents. You received it from me before the parties took their ground. You have had the goodness to peruse it, \& with that I am satisfied. ${ }^{62}$

It is doubtful that Wellington ever saw the document which, long after his father's death, was evidently for the first time published by the rext Duke: in the fifth volume of Despatches, Comespondence, and. Memoranda collectively covering the years $1.819-1832 .{ }^{63}$ However, the morning of the duel the paper remained a matter of concern io Winchilsea who, puting aside any pique about Hardinge's recent conduct, scrupulousiy endeavoured to remove any possibility of misunderstanding about the responsibility of his own second:

In the letter which I wrote hastily to Lord Falmouth late last night... I fear I may have omitted words, which I find in the draft of that letter, to the Effect that Lord Falmouth had not only expressed his entire concurrence in my not frring at the Duke, without which determination on my part he would not have gone out with me, but also told me that I was wrong, as I confessed myself to be, as to the letter which I published in the Standard. If there should be such an omission, I beg it may be corrected .... The fact is he repeatedily made both the observations alluded to in the course of our conversation, as he did the latter clearly \& emphatically to the Duke of Wellington \& you on the ground after I had fired in the air. ${ }^{\text {b4 }}$ 
Curiously, though it might have led Wellington to make inconveniently pointed enquiries about the full contents of his opponent's indicated message of the night before, Sir Henry now responded to Winchilsea by expressing himself as being "quite ready," if Falmouth agreed, to show this post-duel communication to the Duke. ${ }^{65}$ He sent the letter for approval by Falmouth who returned it saying he had no objection to its being shown to the Prime Minister, adding "but ... I think it may best become me to leave this to your own discretion." 66

At the treasury office, three trusted scribesCharles Arbuthnot, and the Duke's private secretaries Edward Drummond and Algernon Greville - copied the previous week's correspondence. The 17 documents selected to make the case for Wellington challenging Winchilsea were then taken to Home Secretary Robert Peel's nearby house for arrangement before being sent off for immediate broadcast in the Courier, ${ }^{67}$ the administration's main daily newspaper. The next day, "Not having been consulted upon the publication of the correspondence which appeared in last evening's Courier," as he put it with some understatement, Falmouth wrote a note of his own to Robert Alexander of the Ultra-Tory Morning Journal-this now in public as opposed to the former private vindication of his recent rote. Basically, he once again explained he knew nothing of the contentious Standard letter until he read it in the paper and made it clear that, after Winchilsea fired in the air, he had been "the first to propose satisfactory reparation." He stressed "that it never was a question with him whether that publication was wrong, but merely wheiher Lord Winchilsea was in a situation honourably to subscribe in the terms proposed after he (Lord Falmouth) was requested to undertake the business." In conclusion, rather ambiguously and indeed mysteriously for a public not privy to its contents, Falmouth aliuded to his delivery of "a sealed. letter, which he had received from Lord Winchilsea on Friday night, to Sir H[enry] Hardinge, who returned it after the affair had been settled, "68

Reactions to the duel, some of which have already been indicated, of course varied according to the circumstances and predilections of the commentator. The story that "The Duke had no halfpence, and was followed and bothered for some time by the Toliman on Battersea Bridge when Hardinge fished out some silver; or a groom came up," was the nonsense of club gossip. Market garden workers were present, at a respectful distance, at the scene of the meeting, and one or more of them may weil have "advised a turn-up with Nature's weapons" - but this humorousiy amongst themselves and not, as some reports had it, ${ }^{69}$ directly to the participants. News of the unexpected event caused a sensation in political circles and high society, Wellington by non-Ultra-Tories being about equally praised for issuing the challenge and blamed for (it was believed) risking his life. Included in the censures was that of Jeremy Bentham, the prominent Radical, who addressed the prime minister as "ILL-ADVISED MAN, "reminding him to "Think of the confusion into which the whole fabric of government would have been thrown had you been killed, or had the trial of you for the murder of anocher man been substituted in the House of Lords to the passing of the Emancipation Bili! " ${ }^{70}$ The artist Sir Thomas Lawrence, who in 1824 painted for Peel perhaps the best known portrait of the Duke, must be counted amongst those who, while thankful that "Fortune or Providence rather ... protected him," still approved of his action whereby "the gross Insult has been avenged, and his personal honor been thus sensitively maintained. "71 John ("Honest Jack") Lawless, one of Daniel O'Connell's Ulster lieutenants on poor terms with his own putative leader, lobbying in London with other members of the Catholic Association, praised Wellington extravagantiy to Charles Arbuthnot and made the unusual assertion that, "Sir, we are twelve of us here, and not one but would, fight for him any day in the week." ${ }^{12}$ More typical of pro-Wellington views, the Scotsman John Gibson Lockhart, Sir Walter Scott's son-in-law, held that "there was no sort of call on the Duke, after beating Buonaparte, to go to war with a Booby. But he could not stand the fling at the fair. His correspondence seems admirable every way, and the whole affar was gone thro[ugh! in excellent taste. ${ }^{473}$

Hardinge's brother-in-law and Durham City electoral patron. Charles Stewart, Lord Londonderry, a tiresome office-hunter, was confidentially not highly regarded by either the prime minister or the Secretary at War. But he all the same received from Sir Henry, cogether with a covering note, a copy of Saturday's Courier as soon as it: appeared. Londonderry's views of the late proceedings, those of a lieutenant-general and a cavalry officer, a Tory borough-monger and landed. 
magnate, may be of interest. He was, it would seem, an exception to the rule in that he had anticipated hostilities.

Many thanks my d[ea]r f[rien]d for the paper. When I first read L[or]d W[inchilsea]'s Letter, I felt satisfied, that it could not, \& ought not to pass unnoticed, \& when once this kind of Affair is entame, no one can pronounce where it may stop. I thank the Almighty that all is so completely triumphant for the Duke \& that your anguish of mind has eas'd. What an Existence you must have had these last 4 Days!! - To dwell for a Moment now, on what might have happen'd to this wonderful man is too dreadfull.

The only period when the meeting might have been averted, was when the Duke wrote his letter N[umbe]r 5. Had Winchilsea been well advis'd, a handsome Apologetick Answer at that Moment might possibly have closed the Business. After this--the Memorandums encreas'd the complication, \& I must in candor own, I do not think either of y[ou]r suggestions could have been. embraced.

L[or]d W[inchilsea], having so grossly err'd, seems nevertheless to have conducted himself boldly \& as a Man of Honor. Lord F[almouth] has prov'd (more than ever), what he always was a Twaddler \& sans, le sens Commun.

I would certainly be cautious (were I in your place), as to publishing, the Alteration in the paper made on the ground,-It stands now so well. for the Duke, that if shewn up more, the other party w[oul]d raise a Cry of the Military bullying the Civil, \& Falmouth's weakness being rode over by your energies. I w[oul]d be equally silent, as to the Duke taking Aim. Because though to go out, ought not to be Child's Play, still this Affair arose out of political writing in very high party Times, and not out of that serious species of Insult \& Injury that generally provoke Duels.

$\mathrm{Be}$ assur'd it is impossible that the Business can stand better for the Duke - \& 'It's all Well That Ends Well'--But Great God!!! What an ordeal [is] Past!!-

... I call'd on the D[uke] \& should write, but fear it would only bother him just now. ${ }^{74}$
A man who also anticipated the meeting was the Duke of Newcastle who, as has been seen, acted for Winchilsea in the handkerchief incident and then luckily avoided being pressed into the duties performed by Falmouth. Newcastle, in his diary, opined that the Ultras" "written apology ... might have been spared"; it may well be believed he said the same, as friendly criticism, to Winchilsea and his second, too. Manifestly he expressed an Ultra-Tory anger in the immediate aftermath of the duel which contrasts with the measured, polite if hardly warm correspondence which passed between those directly engaged on the two sides. But equally plainly Falmouth, as well as Winchilsea, felt resentment at his recent treatment:

Arrived, in London .... L[or]d. Falmouth gave me an account of the Duel. He says that the $\mathrm{D}$ [uke] of W[ellington] behaved in a very churlish. overbearing manner, \& when the affair was over; did not shake hands \& departed sulkily. One is almost tempted to wish that a life so dangerous had been taken away-but one must not indulge in such unchristian feelings. The Duke had the: villainy to take deliberate aim \& has since bragged of the affair as if he were a young subaltern .... Sir $\mathrm{H}[$ enry] Hardinge was very officious \& bullying \& I_[or]d Falmouth had great difficulty in restraining him. The D[uke] of W[ellington]'s time may not yet be come but if may \& that shortly \& terribly for assuredly he is a. villain \& a swine. ${ }^{75}$

Though neither Wellington nor Peel was, after the passage of Catholic emancipation in the spring of 1829 , ever again completely trusted by the Ultra-Tory contingent in parliament, time brought a large measure of public reconciliation which more or less lasted until the final battle over the repeal of the corn laws in 1846 . Indeed, in a symbolic gesture of reunion both Winchilsea and Falmouth were in June 1834 awarded Doctor of Civil Law degrees by Oxford during the same festivities which signalled the duke's installation as university chancellor. In a related connection Wirtchilsea, at least, two years earlier puzzled the Radical editor John Wade who in his Extraordinary Black Book made passing reference to him as "that undefinable peer" since he apparently changed his mind alike on parliamentary reform. and Wellington. ${ }^{76}$ 
(The Earl did, in fact, in 1829 along with Lord Blandford-the rakish great-grandfather of Prime Minister Sir Winston Churchill-and a few other UltraTories broach the issue of parliamentary reform with the intention that an extended franchise would better reflect in the Commons the views of anti-Catholic majority public opinion. But the form that the Reform Bills of 1831-1832, assumed was not what Winchilsea had in mind, and together with nearly all other Ultras he looked. to Wellington to lead the opposition to such measures which they considered disastrousiy destructive).

The Prime Minister challenged Winchilisea, as he later phrased it, because at that junciure "there remained for me only one means of extorting from him an. acknowledgment that he was wrong. "77 The move, and more importantly its well publicized denouement, met Wellington's political requirements; and with that he was satisfied. A careful reading of the relevant documentation, however, reveals that while Winchilsea eventually proved accommodating enough to express "regret," to admit "wrong" in having "unadvisedly" writter the Standard letter, and even to reluctantly go along with Falmouth's pencilled "in apology," it perhaps remains a moot point as to whether or to what extent he ever really repudiated his basic contention that Wellington intended to pass Catholic emancipation at the time of the establishment of King's College. With respect to the period under consideration, the third week of June 1828, history reveals nothing that suggests the duke had changed his mind about the matter. The transformation came at the end of July and beginning of August, after Daniel O'Connell's signal victory in the County Clare by-election, with the development of Wellingion's conviction, long kept secret except from Peel, the Arbuthnots, and Lord Lyndhurst, the lord chancellor, that concession was now a less desperate policy than civil war in Ireland. Strictly speaking, Winchilsea's claim missed the mark by some five weeks, though after August 1828 its connotations in some respects more nearly applied if one accepts that Wellington acted duplicitously toward the ardently Protestant quotient of the Tory party.

The: two Uitras who went to Battersea Fields were almost overwhelned by the intimidating thought of meeting a national icon in what was in theory, and might be in practice, mortal combat. There could on their part be no thought of shooting at the Duke; and
Winchilsea, like numbers before him and after, resolved. to fire not at an opponent but in the air. It is indicative of the extent to which such magnanimous practice had grown that two other men who wrote or received correspondence used in the present study--Buckingham and Londonderry-separately also had occasion to resort to the tactic. Duelling was in decline, with what was bloody, ritualistic tragedy to exilier generations increasingly taking on still largely unconscious elements of injury-free farce, indeed parody. Yet for all the prolix posturing on both sides which issued in an innocuous outcome, and the browbeating of Falmouth, especially, by Hardinge and Hume, two angular characters faced each other when Wellington called out Winchilsea. Further, while the Prime Minister's speedy communication to the Duke of Montrose, informing him that his son-in-law conducted. himself well at the scene, ${ }^{78}$ had an ulterior motive in that the Scottish peer's vote was needed in the Lords, one should also note that: whatever he thought about the political quality of Winchilsea, Wellington in moments of undoubted candour still readily affirmed that his opponent carried himself as a gentleman during their Saturday morning meeting. ${ }^{79}$

Likewise, an editorial column in the proadministration Courier was obviously calculated to reconcile rather than exacerbate divisions within the wider Tory fold, but all the same reasonably fairly stated the case when it allowed as how, "The Duke, being the aggrieved party, could not, of course, resort to the expedient adopted by the Earl of WINCHILSEA. Happily the Duke's fire was without effect, and his Lordship having done all that a brave man could do, did all that a man of honour ought to do-- He made an apology, when an apology could. not be imputed to personal, fear, or to any other than the most honourable feelings." " Years later Roundell Palmer, by then Lord Selborne, who certainly understood, what was expected of the gentlemen of an earlier day, delivered what may serve as a closing commentary in his wry reflection that "though the Duke was, of all men, a champion of law and. order, and Lord Winchilsea was a religious man, and had ... written the offensive woros in his zeal, always at fever-heat, for Protestantism, the one required and the other submitted to give that strange kind of satisfaction, equally irreconcilable with law and with religion, which such an affront was then supposed to rnake necessary." 81 


\section{Acknowledgments}

First, I must thank the staff of McGill University's Department of Rare Books and Special Collections for their courtesy and efficiency in making the Hardinge Papers available to me, and in particular acknowledge the help of Dr. Richard Virr who informed me of the existence of Dr. J.R. Hume's manuscript eye-witness report of the duel to the Duchess of Wellington. Prof. Hereward Senior, of the McGiil Department of History, and Dr. Robert H. Michel (formerly of the McGill Archives, now with the Canadian Centre for Architecture), were good enough to provide constructive criticism of a draft of part of this paper. John Hobbins, of the McGill Libraries' administration, brought my attention to the meaning of the term "delope," and Thomas Brady, LL.B., advised on the question of prime ministerial legal accountability while in office. I have likewise had the benefit of the comments of Peter Macfariane, a graduate student in History at Concordia University, and Peter Leney, a freelance joumalist. With respect to archival materials in Britain, I am indebted to the staffs of several institutions for providing access to their holdings: the Northampionshire Records Office, for the FinchHatton Papers; and the University of Nottingham Library, for the Newcastle Papers. I also take pleasure in expressing appreciation for the assistance provided by Lord Kenyon who most kindly facilitated my study of certain of his family's 19 th century political papers at Gredingtot

\section{Primary Source Abbreviations in Notes}

Arbuthnot, foumal thariet Arbuthot, The Journat of Mrs. Arbuhnor, 1820-1832, eds. Francis Bamford and Duke of Wellington, 2 vols., London: MacMillan \& C.o. Lid, 1950

Broughton, Recollections Lord Broughton, Recollections of a Long Life, ed. Lady Dorchester, \& vols., London: John Murray, 1909 1911

Ellenborough, political Diary Lord Ellenborough, A Pollical Diary 1823-1830, ea. Lotd Colchester, 2 vols, London: R. Bentley, 188 :

Finch-Hation MSS. Papers of George Finch-Hatton, 9in Earl of Winchilsea, Northamptunshire Records Office, Northampion

Gleig, Wellingion G.R. Oleig, The life of Aritur Duke of Wellington, London: Longman, Green, 1864

Greville, Memoirs Charles C.F. Greville, The Greville Memoirs: A Journal of the Reignts of King George IV and King William IV, ed. Henry Reeve, ind ed, 3 vols, London: Longnats, Gren, and Co., 1874

Eardinge MSS.

Papers of Henry Hardinge, 1 st Viscount Hardinge, Department of Rare Books and Special Collections, McGill University
Libraries. The Hardinge Papers were given io McGill University in 1965 by the 4th Viscount Hardinge of Lahore. Lord Hardinge lived in Montreal from the early $1950 \mathrm{~s}$ and was chairman of Greenshields Inc. He died in 1979.

Holland, Son Lady Holland, Elizabeth Lady Holland ro Her Son, 1821-1845, ed. Lord Ilchester, London: John Murray, 1946

Kenyon MSS. Papers of George Kenyon, 2nd Baron Kenyon, owned by Lord Kenyon, Gredingion, Whitchurch, Shropshire

Maxwell, Wellington Sir Herbent Maxwell, The Life of Wellington: The Resioration of the Mantial Power of Great Britain, 2 nd ed., 2 vols., London: Sampson Low, Marsion and Co., 1900

Newcaste MSS. Fapers of Henry Pelham-Clinton, 4th Duke of Newcaste. University of Notingfam Library

Partington, Scont Wilfted Partington, ca., The Private LetterBooks of Sir Walier Scoth, London: Hodder and Stoughion, 1930

Selbome, Memorials Lord Selbome, Memorials, Personal and Family: $1766-1865,2$ vols., London and New York: MacMillan and Co., Lid., 1896-1898

Shelicy. Diary Lady Shelley, The Diany of Frances Lady Shelley, 1787-1873, ed. Richard Edgcumbe, 2 vols., London: John Murray, 1912-1913

[Wade,] Black Book [John Wade, ed.,] The Extraordinary Black Book: An Exposition of Abuses in Church and State, London: Effingham Wilson, 1832; and New York: Augustus M. Kelley, 1970

WND

Duke of Wellington, ed., Despaches, Correspondence, and Memoiunda of field Marshal Anhur Duke of Wellingion, K.G. [1819-1832] 8 vols., London: John Murray, 1867-1880; and Millwood, New York: Kraus: Reprint Co., 1973

\section{Notes}

1. Arthur Weilesley (1769-1852), ist Marquess of Douro and $1 \mathrm{st}$ Duke of Wellington. Bom in Dublin. Educ. Eton, 1781-1784, and at Brussels and Angers, 1784-1786. Gazetted ensign, 73rd Highland Regiment; then lieut. in several regiments. Aidie-de-camp to lord lieutenant of Ireland, 1787-1793. Lieut.-col. commanding 33rd Regiment of Foot in Holiand, 1794-1795. Won great victories and promotions in India, 1797-1805. Fought in Danish campaign, 1808. Commanded in Peninsula, 1809-1814, being awarded highest honours. of Spain and Portugal. Created a British field marshal, 1813. Ambassator to France, 1814-1815, and first pienipoientiary to the 
Congress of Vienna. Commander of the British and Fanoverian forces in the Waterloo campaign, 1815 . Created Prince of Waterloo and field marshal by the Netherlands; also field marshal of Austria, Prussia and Russia, 1818. Commancer-in-chief of the British arriy. 1842-1852.

M.P. for Trim, Irish parliament, 1790-1795; in United Kingdom parliament: M.P. for Rye, 1806; for St. Michael, 1807; for Newport, Isle of Wight, 1807-1809. Chief sec, to lord lieutenant of Ireland and a lord of the treasury, $1807-1809$. K.B., 1804; G.C.B., 1815. Created Marquess of Douro and Duke of Wellington, 1814. D.C.L. of Oxford University, 1814: and chancellor, 1834-1852. Master-gen. of the ordnance, 1818-1827; prime minister, 18281830; foreign sec. 1834-1835; cabinet minister without nhice, 1841-1846.

Married in Duhlin, 1806, Caherinc Pakenham, daugher of 1 ord L.ongford, an Irish Orangeman.

2. George Willam Finch-Hatton (1791 1858), 9 th Earl of Winchilsea and 5 út Earl of Notingham. Fduc. Westminster, ca. 1803-1806:

B.A. Christ's Collegc. Cambridge, 1812. Capt, in Kent militia, 1809: lieut. in Northamptonshire yeomanry, 1819: depuly lord lieutenant of Kent, 1820; lieut.-col. commanding Easi Kent yeomanry, 1830; deputy lora lieutenant of Lincolnshire, 1331. D.C.L. of Oxford University, 18.34 .

Manied, 1814, Georgiana Graham, daughter of the Duke of Wontrose: then, in 1837, Emily Bagot. daughter of Sir Charles Bagot; and thirdly in 1849. Fanny Rice, daugher of Edward Rice, M.P. 3. Stanley Brice Frost, McGill Uhiversily, for the Advancement of Learning (2 vols., Montreal: McGill-Queen's thiversity Press, 1980 and 1984), 1, 129-130.

4. Henry Hardinge (1785-1850), Ist Viscount Yardinge. Joined army in 1799, being gaxetled ensign to the Queen's Rangers in Canadi. Purchased rank of lieut. (1802) and capt. (1804) in infintry. Aitendeư Royal Military College, 1806-1807. l'ronoted maj. (1809) and lieut.col. (1811). Deputy quartermaster-gen. of Portuguese army while dning distinguished service in the Peninsular War under Wellingion's command, 1809-1814. Britisi military commissioner with the 2russians during the Waterloo campaign. K.C.B., 1815; also awarded Orders of villelon the Lion of the 'etheriands, the Tower and Sword of Porugal, st. Fexdinand of opalit, and Giand Cross of the Red ringle of Prussia. L.C.L. of Oxford Universily, 1820 . Gov.-gen of India, 1844-184\%. Creared Viscount Hardinge of Lahore and Kings Sewton, 1846. hasier-gen. of the ordiance, and then commander-inchicf. 1852. Created field marshal, 1856.

ivi.P. for Durham City, 1820-1830; for St. Germans, July-Dec. 1830; for Newport, Comwall, 1830-18.32; for Launcestun, 18.32 1844 . Clerk of the ordnance, 1823-1827, and keb.-Aug. 1828. Sec. at wai, 1828-1830 and 1841-1844. Chief sec. for Ireland, July-Nov. 1830 and Dec.1834-April 1835

Married, 1821, Emily Jane James (nec Siewart), a widow, half. siser of 2 nd and 3 rd viarquesses of Londonderry

5. Lord Hardinge, Viscount Hardinge, $B$, His Son and Private Secretary in India (Oxford: Clarendon Press, 1891), p. 12.

6. Newcastle MGS. NeC 5344, Lord Chandos to Duke of Wewcaste. 18 Aug. 1828. Cf. Kenyon MSS. 52, Lord Fildon to Iady Elizabeth Repton, 1.31 Aug. 1828]: "As to their Intentions ahout the Catholic Question, they lut us know nothing. For that Reason I believe they incend something, of which it will not be pleasant for us to hear. I:or myself, I hope to live to fight the Protestant Battle. I shall... fight in the last...."

7. For a balanced itiroduction to the subject, see G.F.A. Best, "The Protestant Constitution and its Supporters, 1800-1829." Transactions of the Roval ritistorical Socieiy (5th series, VIII, 1958), 105-127. A fuller study of the Catholic emancipation issue will be found in G.I.T. Machin, The Caiholic Question in English Politics, 1820 10 1830, Oxturd: Clarendon isess, 1964.

8. Henry Coleridge served as the secretary of the Committec for Establishing King's College, and Winchilsea's letter to him appeared in the Standard on 16 March 1829. The full text is published in WVD, V, 526-527.

9. Hoid.

10. Arbuthot, Journal, II, 252, entry 12 March 1829

11. WND. 585-586, Wellington to Buckingham, 21 April 1829

12. Hardinge MSS. $315 / 11 / 7,(\mathrm{No} . \mathrm{l}$ ) and (No.2), Wellington to Winchilsea, 16 and 18 March, in Courier, London, 21 March 1829 (newspaper clipning).

13. Ibid., (No.3) and (Yo.4), Winchilsea io Wellingion, 18 March 1829 (newspaper clinping).

14. Greville, Memoirs, I, 193. entry 21 March 1829

15. Ibid. 198, entry 29 March 1829.

16. Ibid. In considering Winchilsca's paraphrased admission "that he really was in such a state of excitement he did not know what he said and did," it should not be forgotten that Greville was a chronicler generally hostile io Uttra-Tories.

17. Newcastle MSS. Ne2 I:3, Duke of Newcasile, Diary, entry 22 Varch 1829.

18. Edward Boscawen (1787-1841), 4ith Viscount Falnouth and Ist Earl of Falmourh. Educ. Eion, 1797-1802. Ensign in Coldstream Guatis, 1807-1808. M.P. for Truio, 1807-1808. Created Eall of Falmouth as one of George IV's coronation peers, 1821. Recorder of Christchurch, Truro. and Fenzance. D.C.L. of Oxford University, 1834 .

Married, 1810, Ame Frances Bankes, daughter of the Clira-Tory M.P. Henry Bankes, of Kingston House, Dorsetshire.

99. Hardinge MSS. 315/11/7, Yalmouth to [Robert Alexander], editor of the Morning Joumal, 22 March, in Courier, London, 23 March 1829 (newspaper clipping).

20. Sir Leslie Étephen and Sir Sidney Lee, edis. The Dirtionary of Naitonal Biography (22 vols. I.ondon: Oxford Lniversity Press. 1960), II, 881

21. Ihid., VII, 20-21

22. Iinch-Hatton visS. 4608. Winchilsca io Chandos, 26 Aug. 1828

23. Greville, Memoirs, I, 192, eniry 21 March 1829.

24. Ifolland, Son, p. 96, Lady IIolland to Henry Edward Fox, 14 Feb. 1829

25. Selborne, Memorials, I, 158, 160.

26. Hardinge MSS 315/1/20, Wellington to Hardinge, 19 iviatch 1829.

27. Ibid. $315 / 11 / 7,(90.5)$, in Courier, London, 21 March 1829 (newspaper clipping)

28. Ibid. Falmouth to [Robert Alexander], editor of the Morning Joumal, 22 Viarch, in Courier, London. 23 March 1829 (ncwspaper clipping).

29. Bbid. 21 ivarch, (\$o.7), Winchilsea Memorandum, 19 March [1829] (newspaper clipping)

30. Ibid., (No.5), Yardinge Micmorandum, "Eight o'Clock Evening." "Thursday, half-past Nine o Clock Evening, "Friday Miorning, "1920 March [1829] (newspaper clipping).

31. rbid. 315/1/20, Falmouth to Mardinge, "Confudential Falnouth House ... 8 a in.," 20 March 1829

32. Lbid. 315/11/7, (Vo.8), Wellington Memorandum, "in the Morning," 20 March, in Courier, London, 21 Viarch 1829 
(newspaper clipping).

33. Ibid., (No.9), Hardinge Memorandum, "N.B. - The original of this delivered to Lord Falmouth," 20 March [1829] (newspaper clipping).

34. Ibid., (No.10), Falmouth Memurandum, 20 March [1829] (newspaper clipping).

35. Ibid., (No.11), Harelinge Memorandum (to Falmouuli), "Two o'Clock," 21. [sic 20] March; ibid., (\$o.12), Falmouth to Hardinge, "Half-past 3, P.M.," 20 March 1829 (newspaper ciippings).

36. Ibid, (No.14), Wellingเon to Winchilsea, "half-past six F.M.," 20 March [1829] (newspaper clipping).

37. Ibid., (No.13), Hardinge to Falmourh, 20 March 1829; ibid., (No. 15), Falmouth to Hardinge, "Half-pasi Eleven, p.m., " 20 March 1829 (newspaper clippings).

38. Gleig, Wellington, p. 348.

39. Hardinge MSS. 3i5/1/20, Hume to Hardinge, "Curzon St[reet] 9 o'clock," [20 March 1829].

40. loid. 315/11/7, (No.16), Winchilsea to Wellington, [20 March], in Courier, London, 21 March 1829 (newspaper clipping).

41. Except where otherwise indicated, the account of the events at Battersea Field's is based on Hume's report to the Duchess of Wellington in Hardinge MSS. 315/8/14. Dated the same day as the duel, 21 Miarch 1829, but lengihy and detailed enough that its final version may have required several days to complete, some of its passages - including parts of the dialogue - stem a bit contrived. This may in part have been due to Hume simply creatively comperisating for the inexactitude of his memory, but at the same time the narrative as a. whole appears to have been an attempt by its author to enhance his standing with the Wellingtons, in some places by obsequiousness. Yet Hume's is the only detailed eye-witness account of what happened on the ground. Hardinge MSS. 315/8/14 contains two copies of the documene in different handwriting (one of them evidently bearing llume's holograph signature), which are iextually identical but for some variations in capitalization and punctuation. Another, published. version is in WND, V. 539-545. IJowever this, ediced by Wellington's eldesi son and heir, as will be noted omits certain passages found in the Fardinge MSS. copies of Hume's original rendition of the duel. 42. Tardinge MSS. 315/1/20, Winchilsea to Hardinge, "7 Suffolk Sil reet] Saturday Morning 10 o'clock" [21 March 1829]; ibid., rialmouth to Hardinge, "Falmouth House ... 1/4 to 11 a.m." 2 i March 1829. The note was evidently delivered by Falmouth to Sir Henry beforc the parties departed for their rendezvous, as the watchful Hume did not see it transmitted at the scene. Indeed, Hume in his report rather confusingly represents Falmouth as asking Hardinge if the latter had even received the document, when of course Winchilsea's second had himself delivered it.

43. Hardinge's annotation in Hardinge MSS. 315/8/14, pp. 1-2, Hume Report to Duchess of Wellington, 21 March 1829. Hardinge's annotation does noc appear in WND, Y, 540.

44. Maxwell, Weilington, II, 234. The duke's two gruff sentences of instuction to Hardinge about stepping out the ground and the placement of Winchilsea were omitted by fiume in his report to the duchess, but recounted later by him to Admiral Sir George Seymour. Quoted consecutively by Maxwell, they are here separaied and more logically integrated into the narrative based on Hume's report. There are severat variants of the reference to Winchilsea. Cf. Ellenborough, Political Diary, I, 403, entry 21 March 1829: "Lord Winchilsea was placed so near a ditch that the Duke said he was on the point of crying out, "Damn it, if you place him there, he will fall into the ditch'", and Broughton, Recollections, II, 313: "... he said to
Haruinge, 'Don't let him stand so near the ditch, or he'll tumble into it if I shoot him." However, the version used by Naxwell is probably the most authentic.

45. Ellentorough, Political Diary, 1, 403, entry 21 March 1829. Falmouth's attempt to have the distance set at 18 paces, intended to lessen danger to the principals, is not mentioned in Hume's report. 46. Maxwell, Wellington, II, 234.

47. Ilardinge MSS. 315/1/20, Hardinge to Falmouth, n.d. [21 March 1829]. There are two similar though not identical copies of Hardinge's protest, but the quoted draft, hastily written in pencil, appears to be the one aciually carried to the field and read on the occasion of the duel.

48. Maxwell, Weliington, II, 234-235

49. Hardinge MSS $315 / 1 / 20$. Mardinge Memorandum, "1/4 past \& o'clock," 21 March 1829. Addressed to "My Lord Falmouth," this document hegins as one or two drafts of Hardinge's protesi, but continues as a brief memorandum of events from that point in the duel. Some of its content is identical, or nearly so, so phrases found in Hume's report to the duchess.

50. Ibid. MSS. 315/11/7, (No. 17). Memorandum, 21 March 1829 (newspaper clipping). Hume's report indicates that this item, or at least the draft carried to the field, was in Falmouth's handwriting; but Winchilsea's vital interest would certainly have made him a co-author if not in reality the sole one. The same text, with the addition of Hume's initials and his two signarures in verification of the "in apology", is published in WND, $\mathrm{V}, 538-539$.

51. Another passage of panegyric, addressed directly to the duchess by Hume rather than presented as quoted conversation, is sycuphantic (Hardinge MSS. 315/8/14, p.5, Hume Repor to Duchess of Wellington, 21 March 1829):

In meetings of this nature the principals are supposed to cornmin themselves entirely to the guidance of their seconds, $\&$ thus become in their hands almost subordinate agents. On this occasion ihe Duke conformed himself stricily to this rule, $\&$ I could not help admiring how muekly \& submiscively he conducted himself throughout the whole of this affair.

To those who, unacquainied with the Duke, have only looked at his greatness \& recollect him at the head of his army in all the triumph of Victory, driving his enemies before him from the Tagus to the Garonne in one tide of uninterrupted success; or who, after he had vanquished his great rival on the plain of Waterloo and arrived at one bound under the walls of Paris, have beheld him in that Capital in all the splendour of conquest, surrounded by Emperors and Kings, himself the most distinguished of all the members of thai brilliant assemblage, fixing the houndaries of kingdoms and controuling by his single word the destinies of the world, this may appear scarcely credible. To others who know the Duke well it will excite neither wonder or astonishment, for, whilst he is perfectly confident in himself, and well aware of the respect due to his great actions, no man assumes less. With the most perfect knowledgc of human nature he has always set a just value on popular applause \& has never for a momeni allowed himself to be blinded by fortune or intoxicated with praise. In his honest pride there is no arrogance, in his dignity no haughtiness, in his superiority no vain-glorious display, but plain, simple \& natural in his manner, he is without exception the most unaffected of men. In all siruations \& on all important occasions he presents the same person. Calm, moctest, unassuming, yet dignified, resolute \& firm; easy, 


\section{The Wellington-Winchilsea Duel of 1829}

unembarrassed, never losing for a second his selt-possession never impatient or hurried.

52. ive reference to Winchilsea's "remarks on Sir Henry Hardinge's manner of conducting the correspondence" appears in WND, V, 544. i ieither does Winchilsea's assertion a moment later about the duke caking "deliberate aim" at him, nor Hume's rebuttal which includes a marginal note by the doctor to the effect that Wellington subsequently confirmed he hesitated upon seeing that his opponent made no attempt to present at him (Hardinge MSS. 315/8/14, p.5. Ilume Report to Duchess of Wellington, 21 ivarch i829).

53. Selborne, inemorials, i, 155; Gleig, Wellington, p. 349

54. Hardinge MSS. 315/1/20, Yardinge Miemorandum, "1/4 past 8 o'clock," 21 March 1829. Arbuthnot, Journal, II, 257, entry 22 March 1829; Shelley, Diary, II, 188, Harrict Arbuthnot to Lady Shelley, 21 iMarch 1829

55. Ellenborough, Political Diary, I, 403, entry 21 March 1829. Cf. Broughion, Recolleciions, III, 313: "After the affair was over, the Duke said to Hardinge. "I only fired at his legs."

56. Broughton, Recollections, III, 313.

57. The İrish or Clonmel rules, drawn up at the Clonmel summer assizes in 1777 and with rough humour dubbed "the twenty-six commandments" in Counly Galway, for the most part codified existing custom and seem to have thereafter served as the basis of duelling theory, though (especially in Britain) not necessarily of duelling practice. Nonetheless, by this standard, if both parties agreed to the terms of settlement-as was, after all, the case at Battersea Fields-hostilities could be honourably terminated after only one exchange of fire. However, Winchilsea's tactic of shooting in the air was, by the same token, another matter. Rule Xir reads as follows: "vo dumb firing or firing in the air is admissible in any case. The challenger ought not to have challenged without receiving offence, and the challenged ought, if he gave offence, to have made an apology before he came on the ground; therefore children's play must be dishonourable on one side or the other and is accordingly prohibited." The full text of all 26 rules of the Clonmel Code is published in Roberi Baldick, The Duel: A History of Duelling (London: Chapman \& Hall, 1965), pp. 33-36. Technically, Winchilsea "deloped" by deliberately firing in the air. Cf. The Oxford English Dictionary (2nd ed., 20 vols., Oxford: Clarendon Press, 1989), IV, 425. But the term "delope" never achieved general usage. 58. Shelley, Diary, II, 188-189, Harriet Arbuthnot to Lady Shelley, 21 March 1829

59. Arbuthnot, Journal, II, 257-258, entry 22 March 1829. Cf. also Greville, Memoirs, 1, 195, entry 26 March 1829: "The ring, it seems, was highly pleased with the Winchiliea affair, and he said, " $i$ did not see the letter (which is probably a lie); if I had, I certainly should have though it my duty io call your attention to it.' Somebody added that 'he would be wanting to fight a duel himself.' [Lord] Sefton said, "He will be sure to think he has fought one."

60. Hardinge wSS, 315/1/20. This significant letter from Winchilsea to Falmouth is a copy in Hardinge's handwriting. The same item with a few variations in punctuation, capitalization and spelling appears in WND, V, 539

61. Hardinge MSS. 315/1/20, Hardinge to Falmouth, "11 White-Halt Place ... 10 o'clock a.m." 21 March 1829.

62. Ibid., Falmouth to Hardinge, "Falmouth House ... 1/4 to 11 a.m." 21 March 1829

63. See note 60 above.

64. Hardinge MSS. 315/1/20, Winchilsea to Hardinge, "7 Suffolk St[treet] Saturday Morning $100^{\prime}$ clock" [21 March 1829].
65. Ibid., Hardinge to Winchilsea, 11 White-Hall [Place], 21 March 1829

66. Ibid., Hardinge to Falmouth, 11 White-Hall Place, 21 March 1829; ibid., Falmouth to Hardinge, Falmouth House, 21 March 1829.

67. Ellenborough, Political Diary, I, 403-404, entry 21 March 1829.

68. Hardinge MSS. 3 15/11/7, Falmouth to [Robert Alexander], editor of the Morning Journal, 22 March, in Courier, London, 23 March 1829 (newspaper clipping).

69. Partington, Scon, p.41, John Gibson Lockhart to Sir Walte: Scott, 25 March 1829; Morning Herald, London, 23 March 1829, in Baldick, Duel, p.106.

70. WND, V, 546, Bentham to Wellington, 22 March 1829. There followed a somewhat stranger letter which read, in par (ibid., 554, Bentham to Wellington, 23 March 1829): "I must at you once more. I am an Englishman. More than that, I have my designs upon you. I want to make you do what Cromwell tried at and found it was too much for him. ' cannot afford to tose you. Your counury remains plunged by you into a danger you seem not to be awale of. I am." 71. Hardinge MSS. 315/1/20, Lawrence to Hardinge, Russell Square. 22 March 1829

72. Greville, Memoirs, I, 196, entry 26 March 1829.

73. Partington, Scott, p.41, Lockhar to Scott, 25 March 1829

74. Hardinge MSS. 315/1/20, Londonderry to Hardinge, "Sar[urda]y Night" 21 March 1829. For the text of Wellington's "Letter N[umbe]r 5" alluded to by Londonderry, see above, p. 76.77, the communication dated "London, March 19, 1829."

75. Newcastle MSS. Ne2 F/3, Duke of Newcastle, Diary, entries 22 , 26 March 1829

76. [Wade,] Black Book. p. 540.

77. Gleig, Wellington, p. 349 .

78. Greville, Memoirs, I, 195, entry 26 March 1829

79. Ellenborough, Political Diary, 1, 403, entry 21 March 1829; Gleig, Wellington, p. 349. Cf. also Hume's estimation (ilardinge MSS. $315 / 8 / 14$, pp. 5-6, Hume Report to Duchess of ellinglon, 21 March 1829):

... I have great pleasure in bearing cestimony to the gentleman-like behaviour of Lord Winchilsea. His manner throughout was exceedingly becoming - no haste, no forwardness, no presuming. His countenance, which is very pleasing, wore a certain expression of pensiveness and as i thought, of regret, as if dissatisfied with himselt, and, as he seemed to have put himself entirely into the hands of his friend, I confess I felt in spite of me a degree of interess \& concern for him.

80. Hardinge MSS. 315/11/7, Courier, London, 23 iVarch 1329 (newspaper clipping).

81. Selbome, Memorials, I, 154-155. 


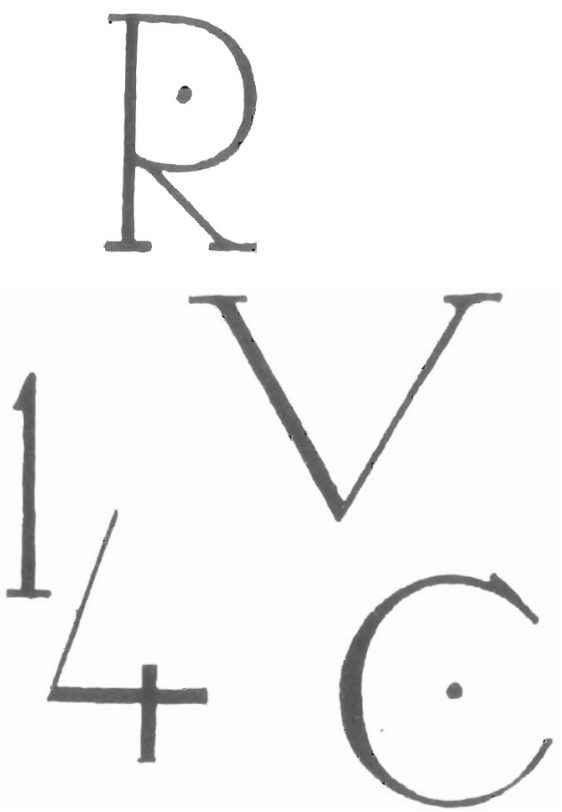

$\infty$

\section{OFFICERS}

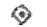

President

Miss Isabel McCll

Vice-President

Miss H. S. Gevtllis

Sec'y-Treasurer

Miss Margaret McNivex

Class Representative Miss Alice McKeli

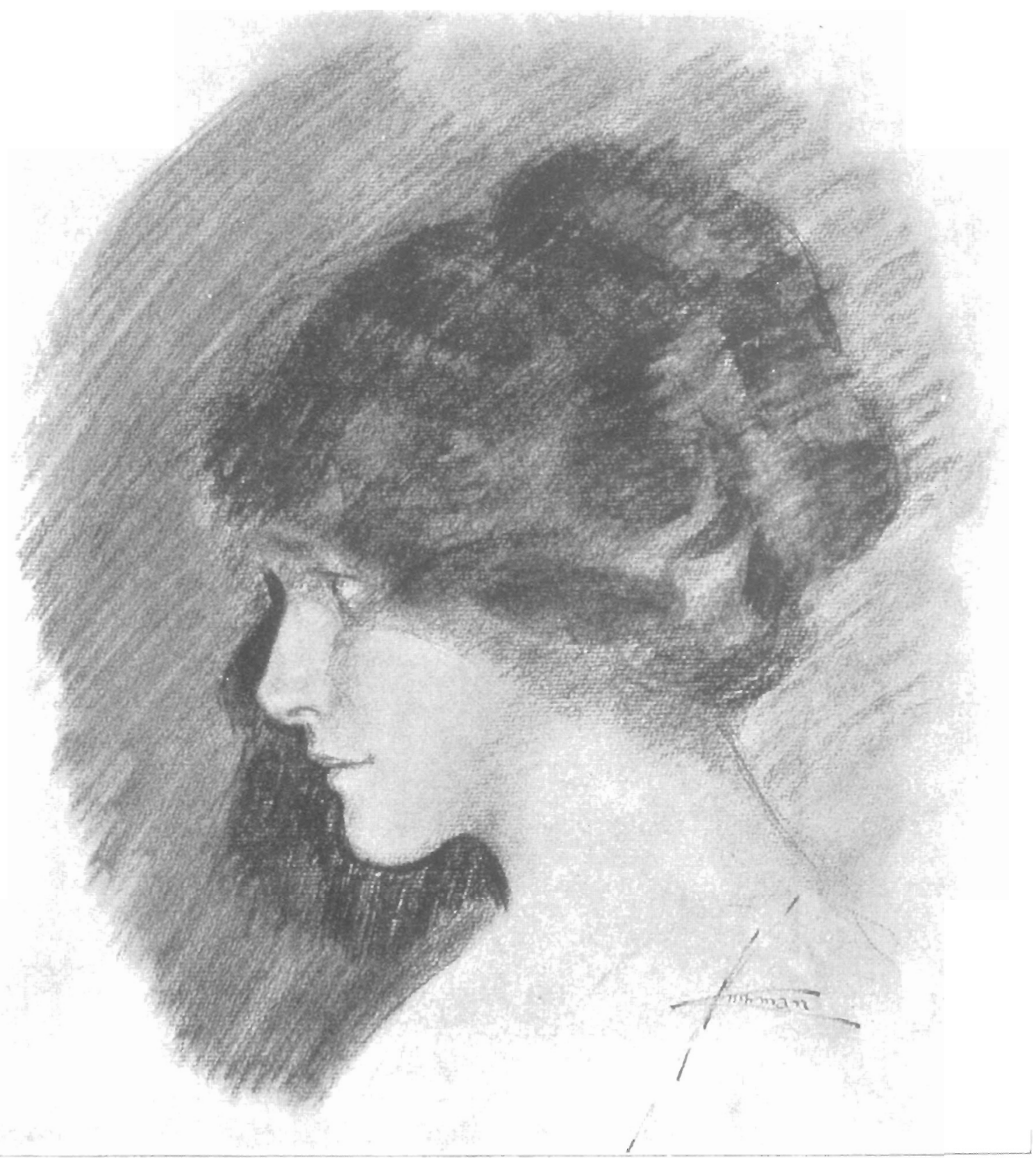

"Beautiful creatures with Cléo de Mérode hair ..." (Old McGill, v. 17, 1914, p. 31) 


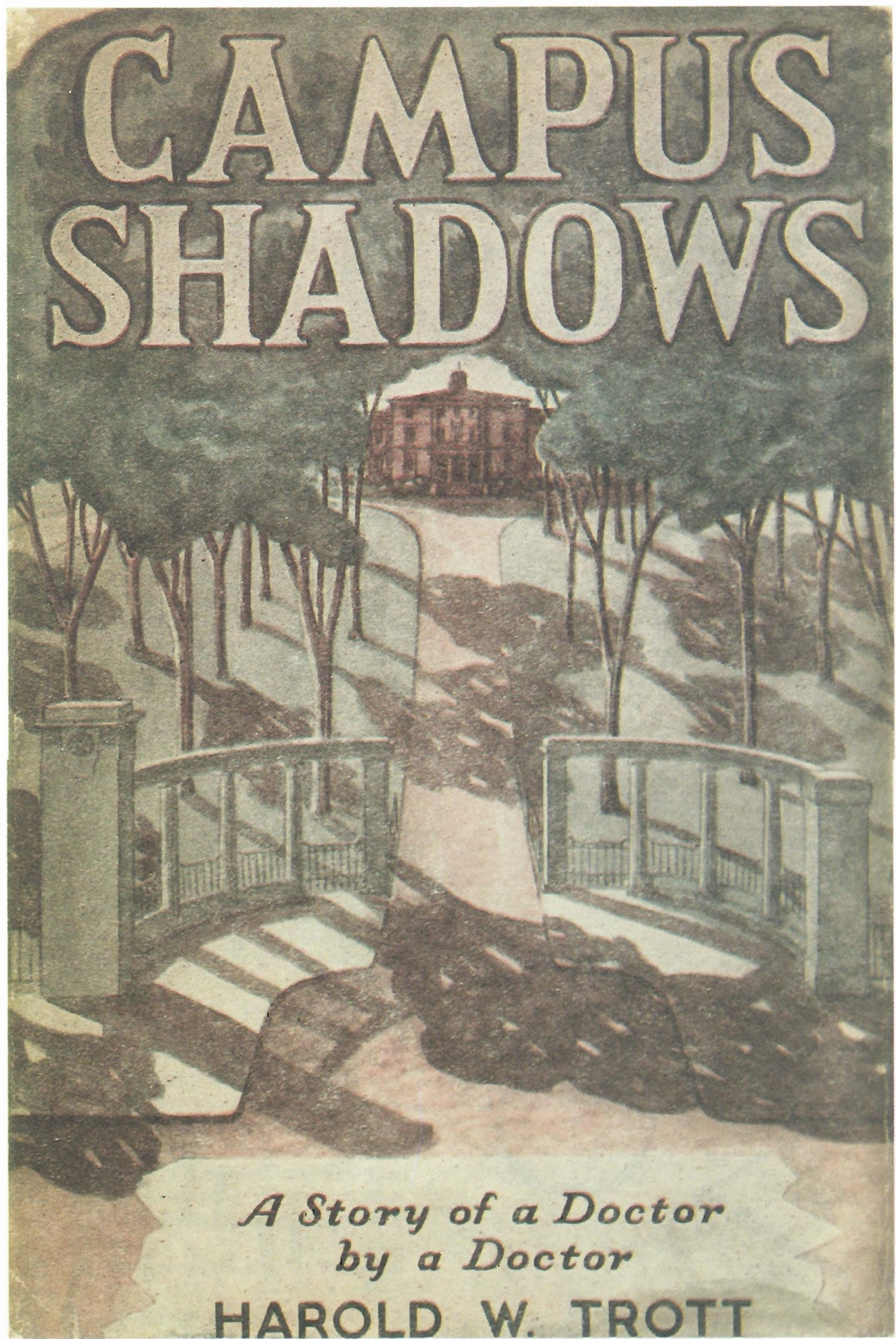

Book jacket of H. W. Scott's Campus Shadows, 1946. 


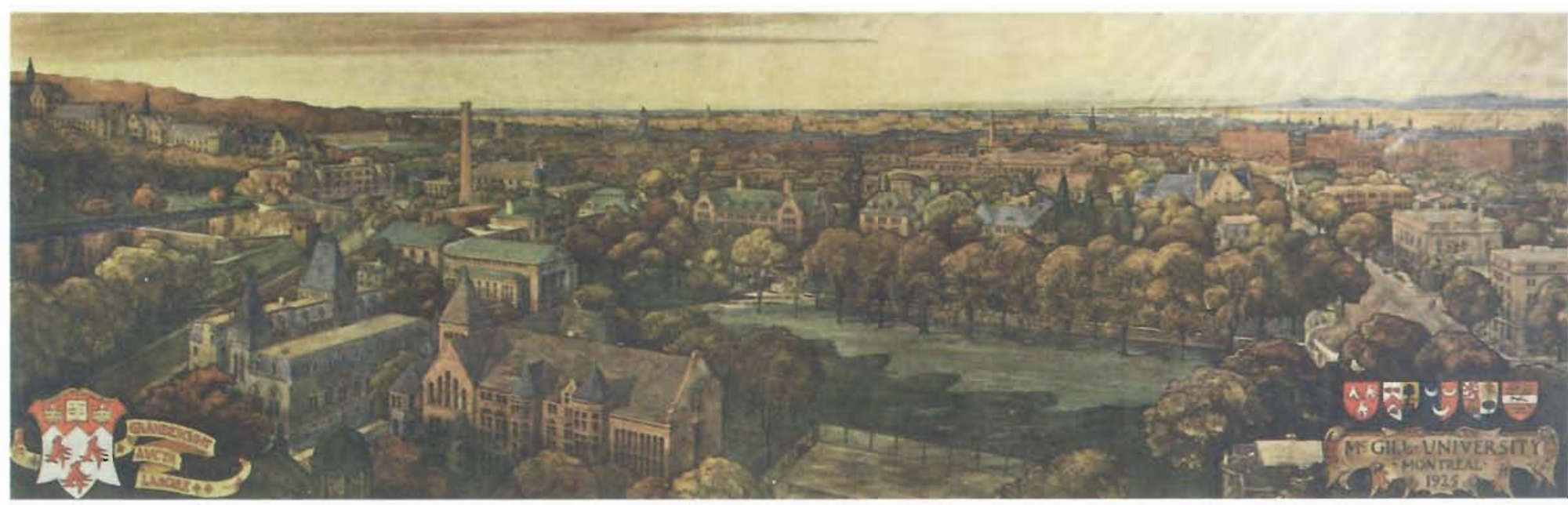

Reproduced from a colour print by Percy Nobbs, 1925

(Blackader-Lauterman Library of Architecture and Art. Canadian Architecture Collection) 


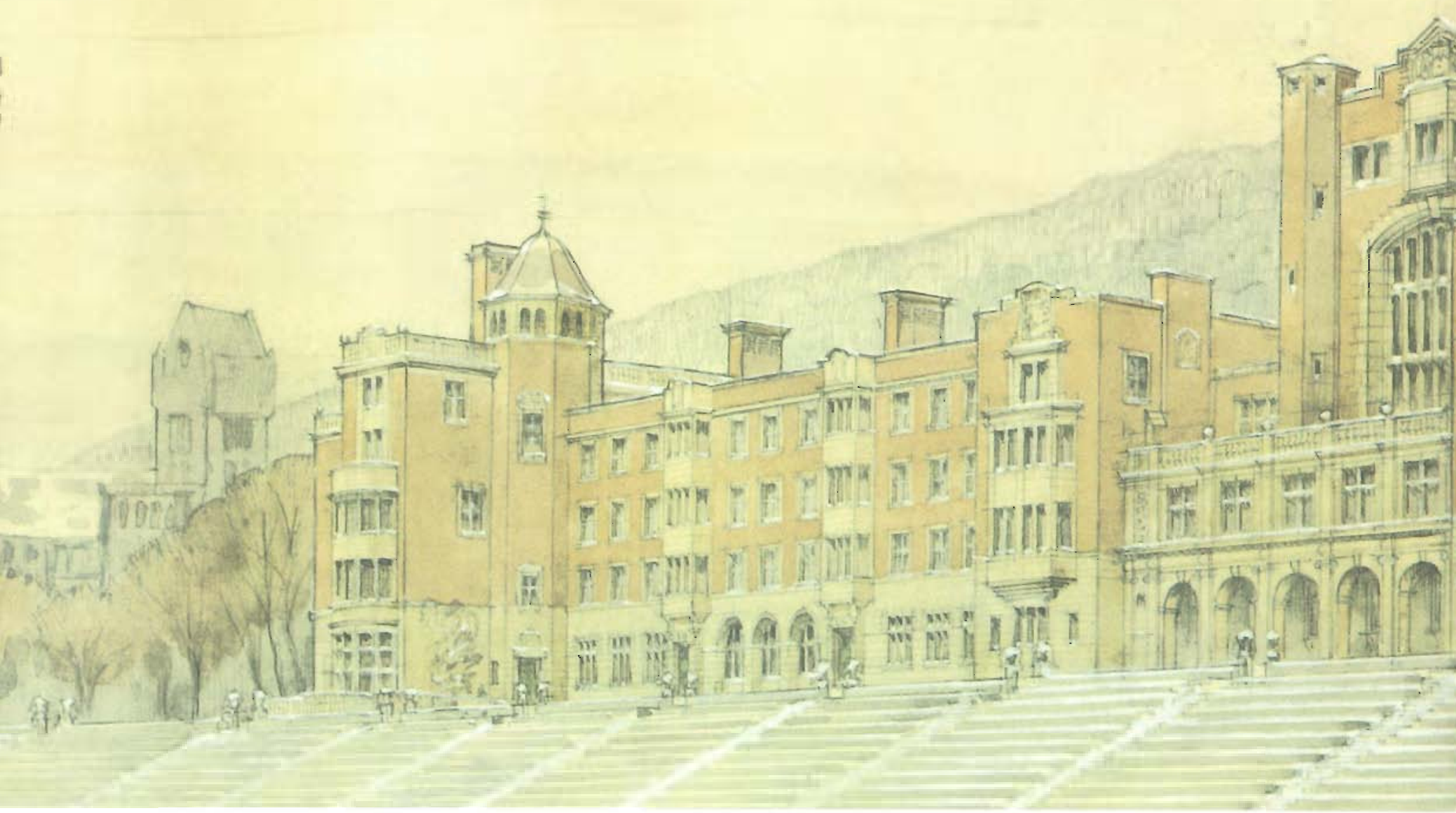

Proposal of Development of Macdonald Park by Percy Nobbs, 1913.

Detail of gymnasium stands, and student residences. Water colour on paper.

(Blackader-Lauterman Library of Architecture and Art. Canadian Architecture Collection) 


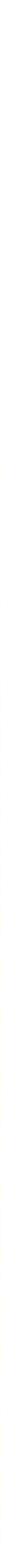




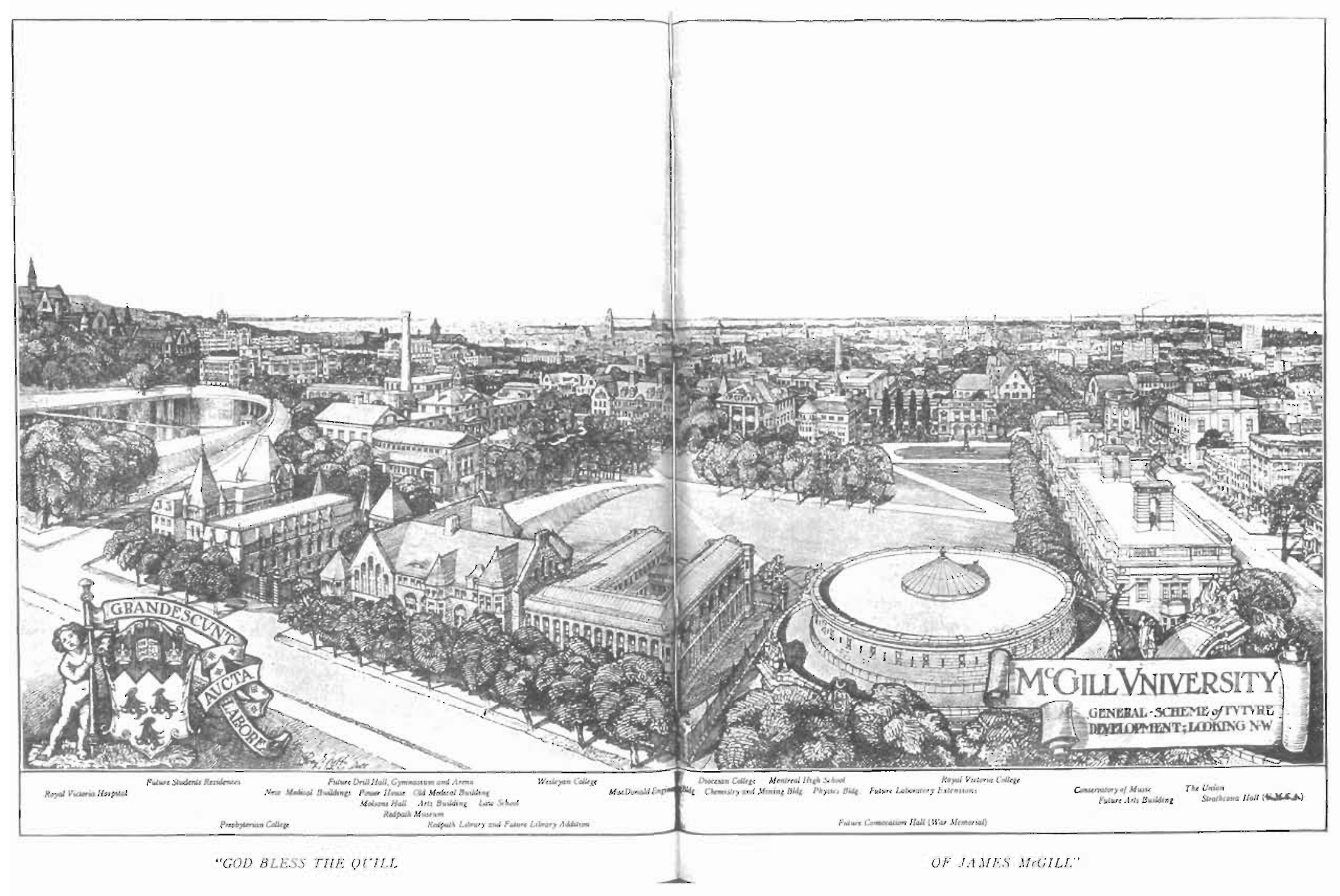

Development plan of McGill Campus envisioned by Percy Nobbs, 1920.

(Blackader-Lauterman Library of Architecturc and Art. Canadian Architecture Collection) 


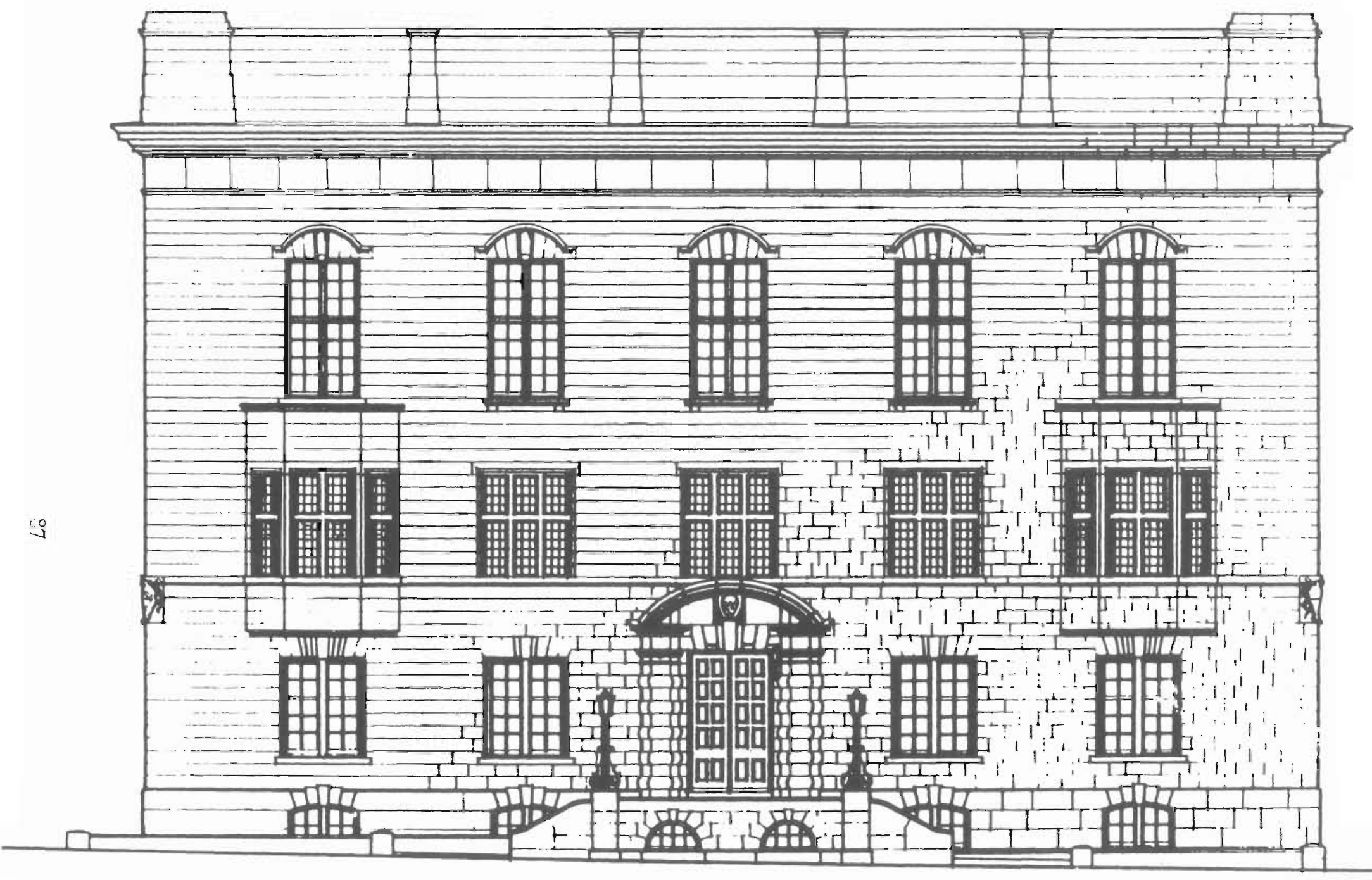

Eleverion to chentinoole climeal

MIGIL Thiversily Thion. 


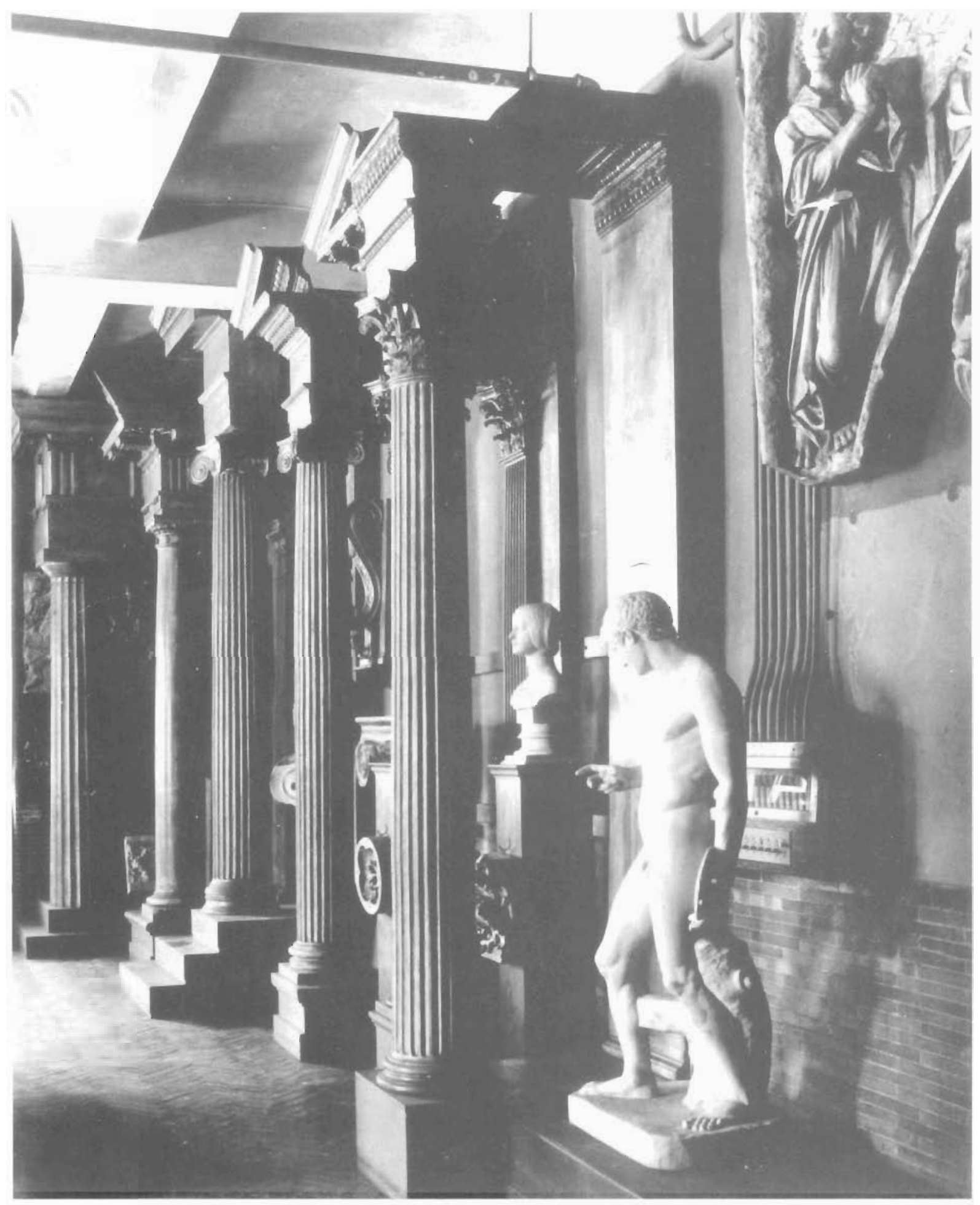

Casts and models in Architectural Department, Macdonald Engineering Building 


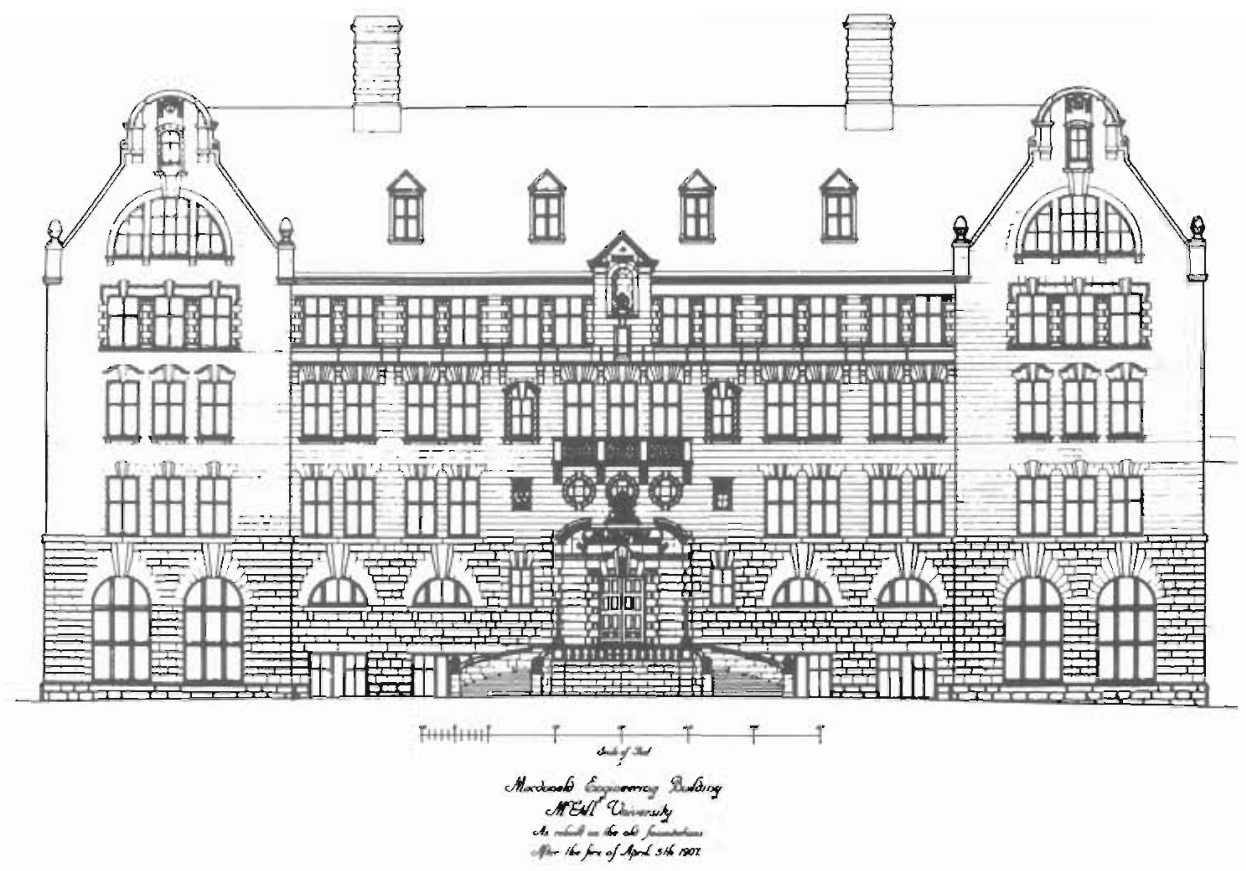

(Blackader-Lauterman Library of Architecture and Art. Canadian Architecture Collection)

-Th" Grit "Vmipersify librung.

Secrive fixfeasion to Siacks.

1921.
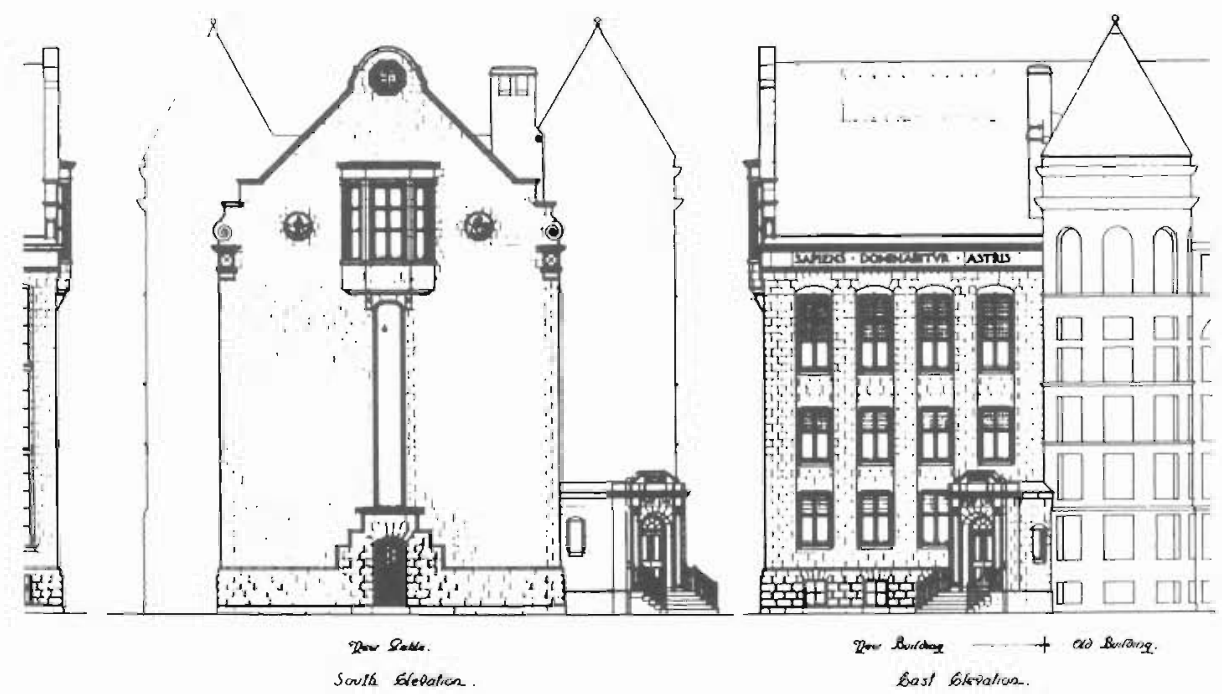

(Blackader-Lauterman Library of Architecture and Art. Canadian Architecture Collection) 


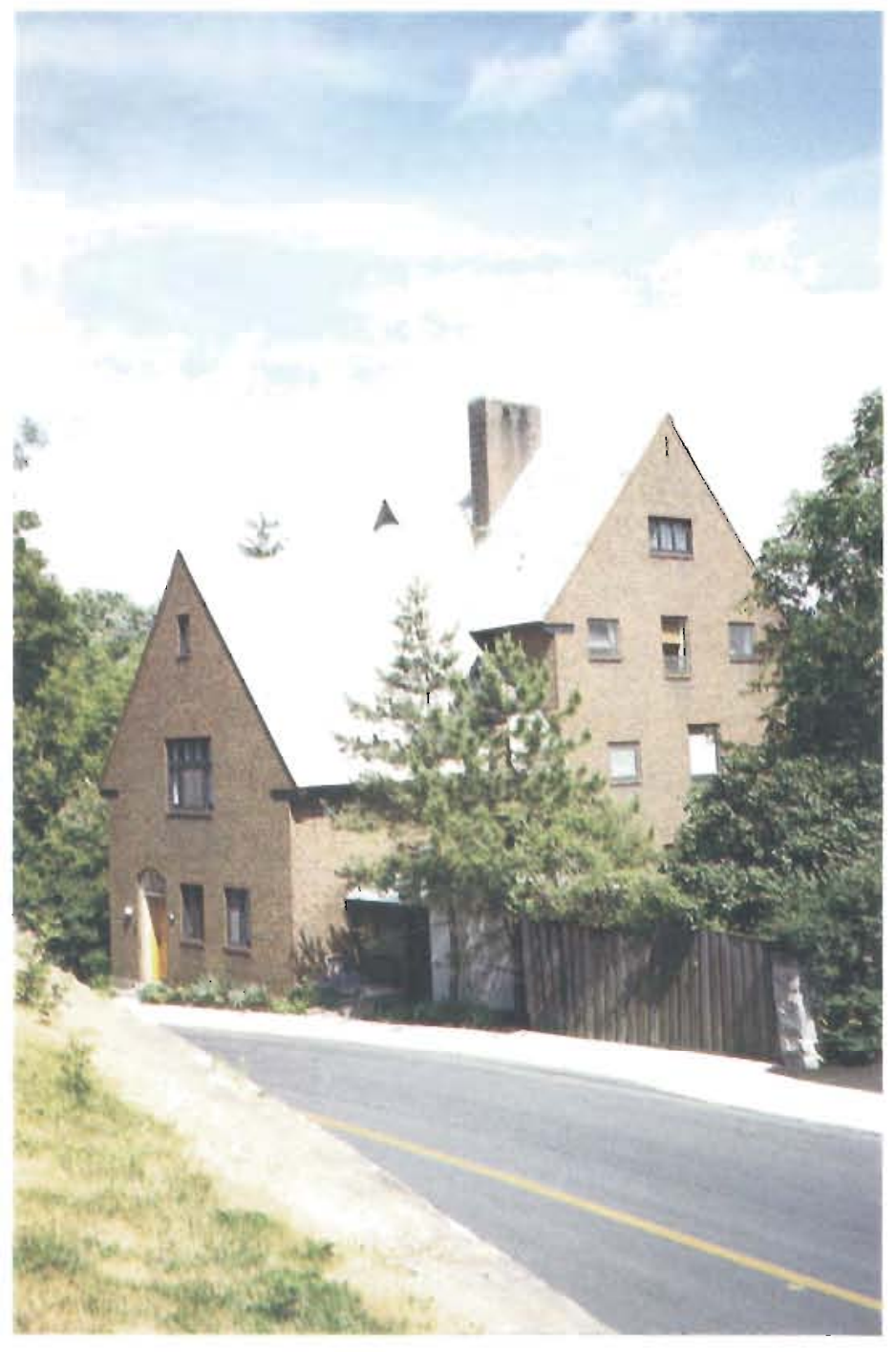

Nobbs Family Residence, 38 Belvedere Road.

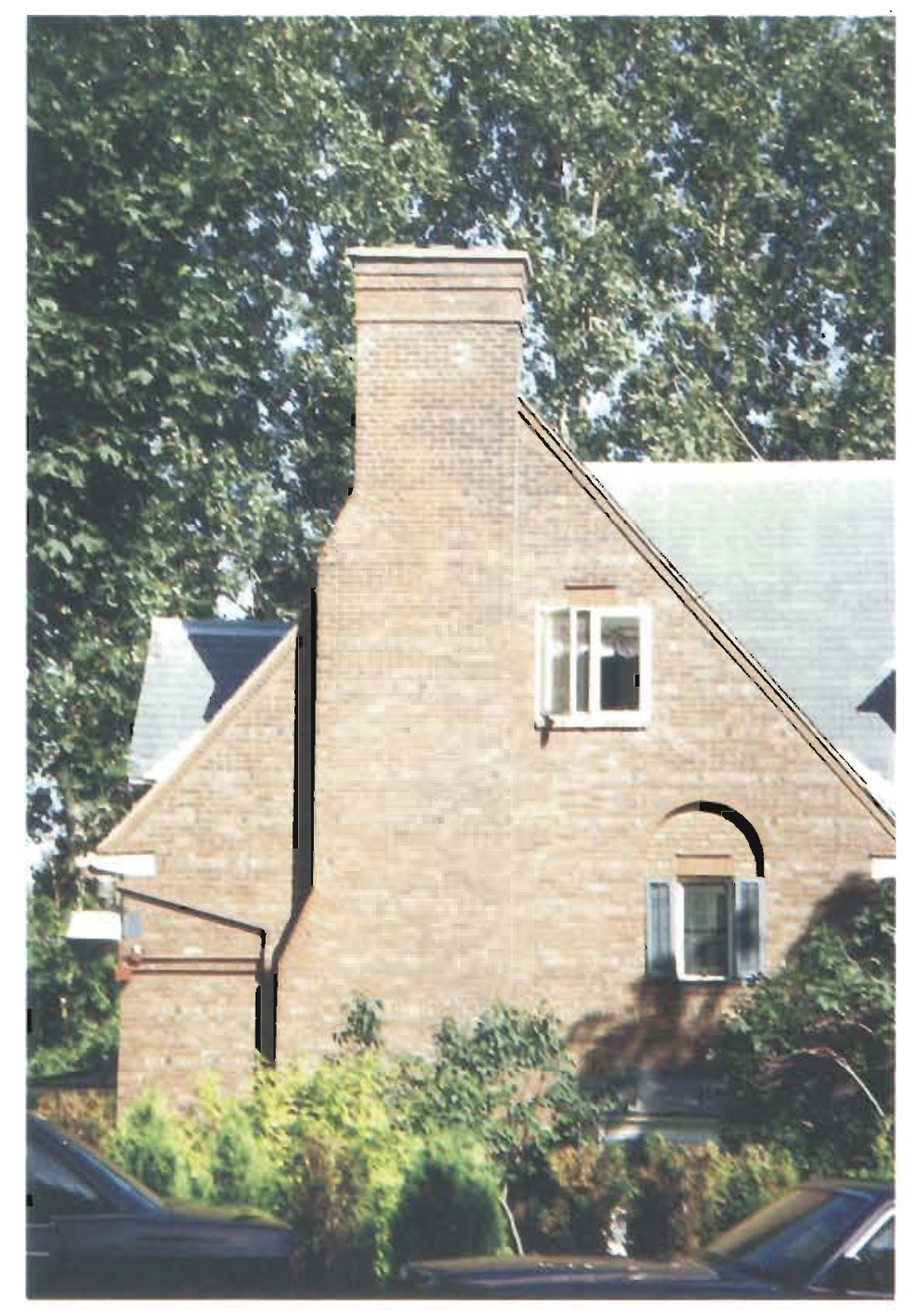

8

3172 The Boulevard, Westmount. 


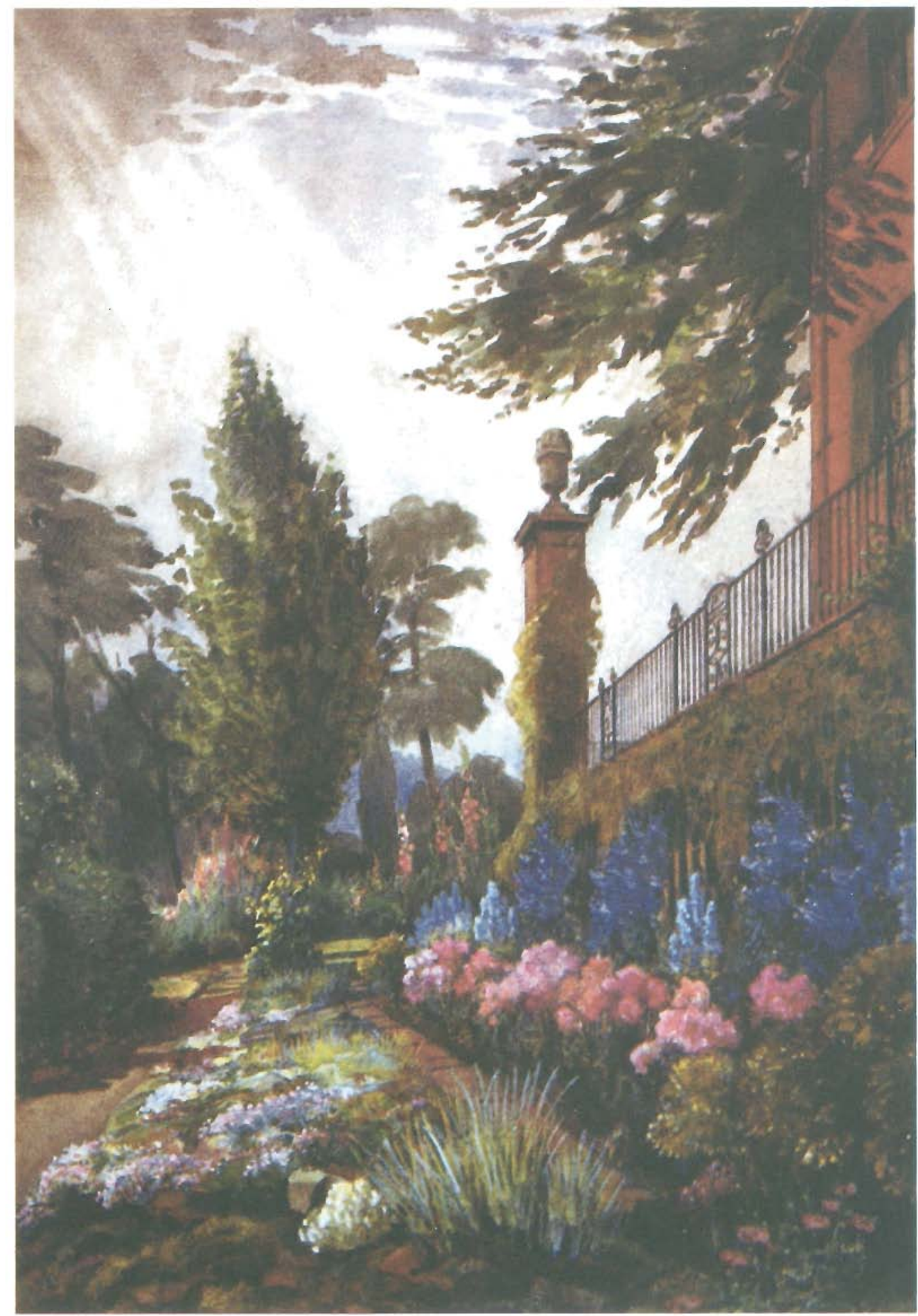

Garden of Nobbs House, Westmount, 1923.

(Nobbs Family Collection) 

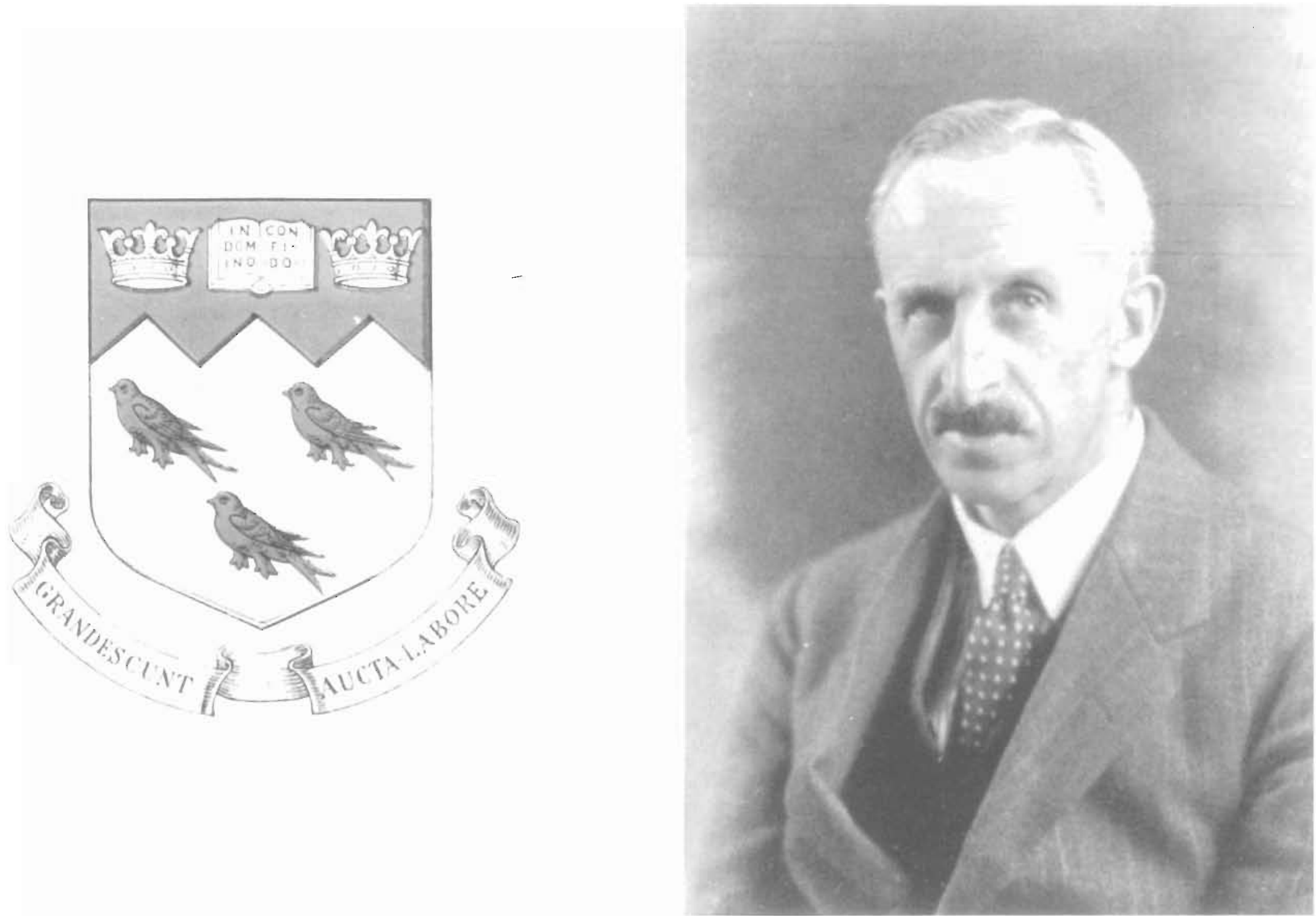


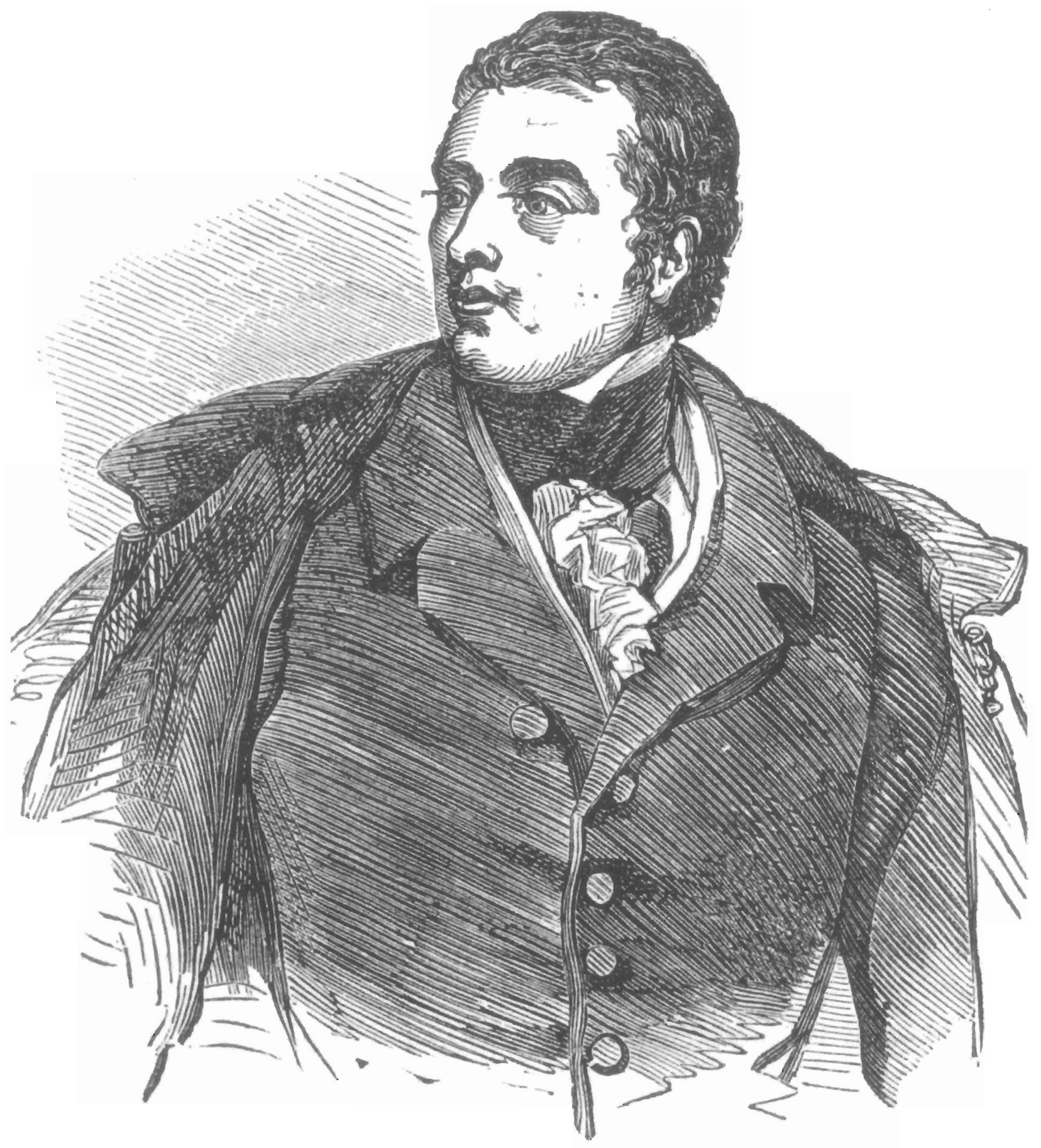

Lord Winchelsea

Engraving reproduced from The Life of Field Marshall the Duke of Wellington, by J.H. Stocqueler. 2 v. Aiden, Beardsley and Company, 1853. v. 2, p. 147. 


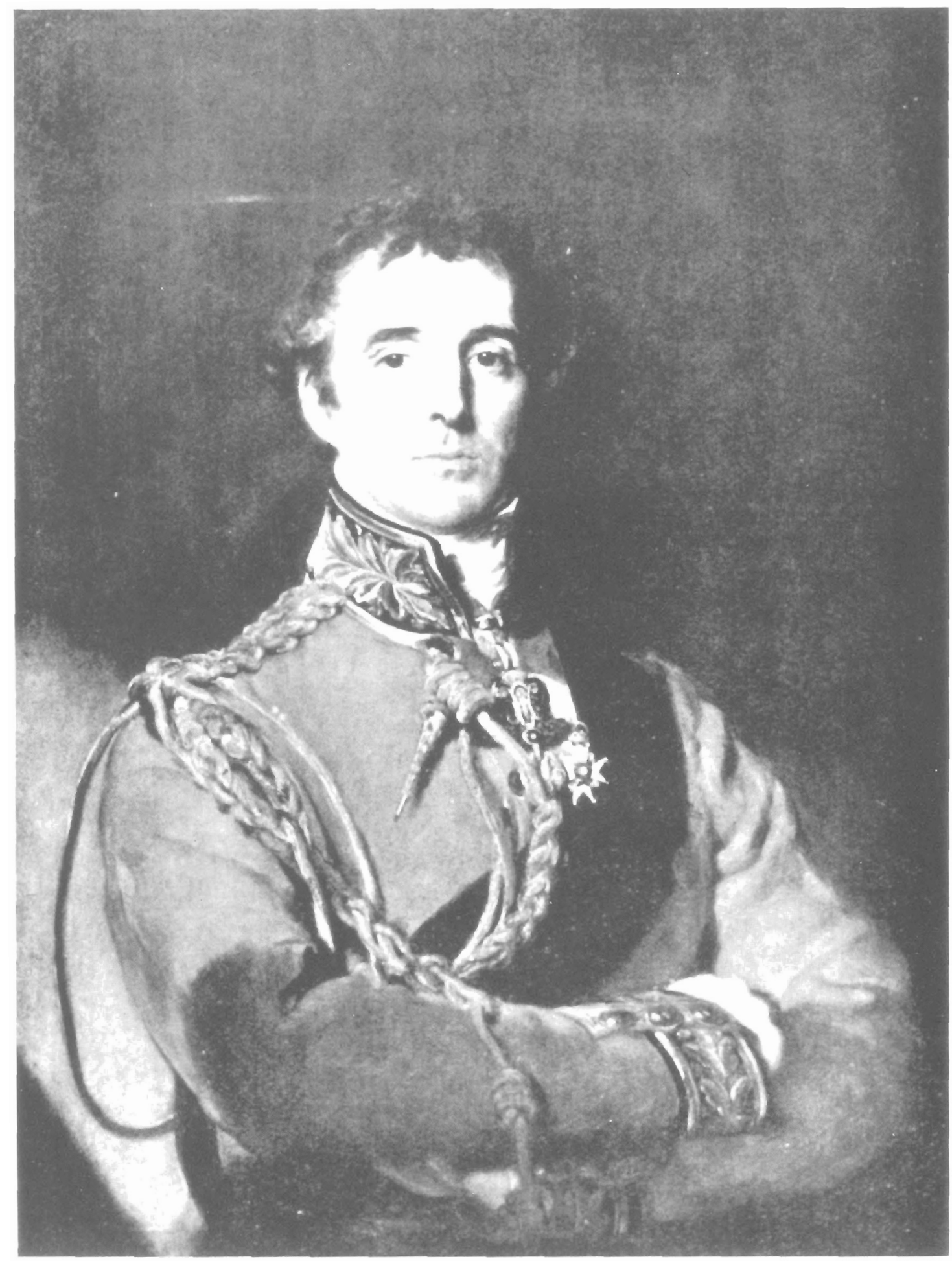

Lord Wellington. Painting by Sir Thomas Laurence.

Reproduced from Wellington By John Fortescue. London: Williams and Norgate, 1925. (Frontispiece) 


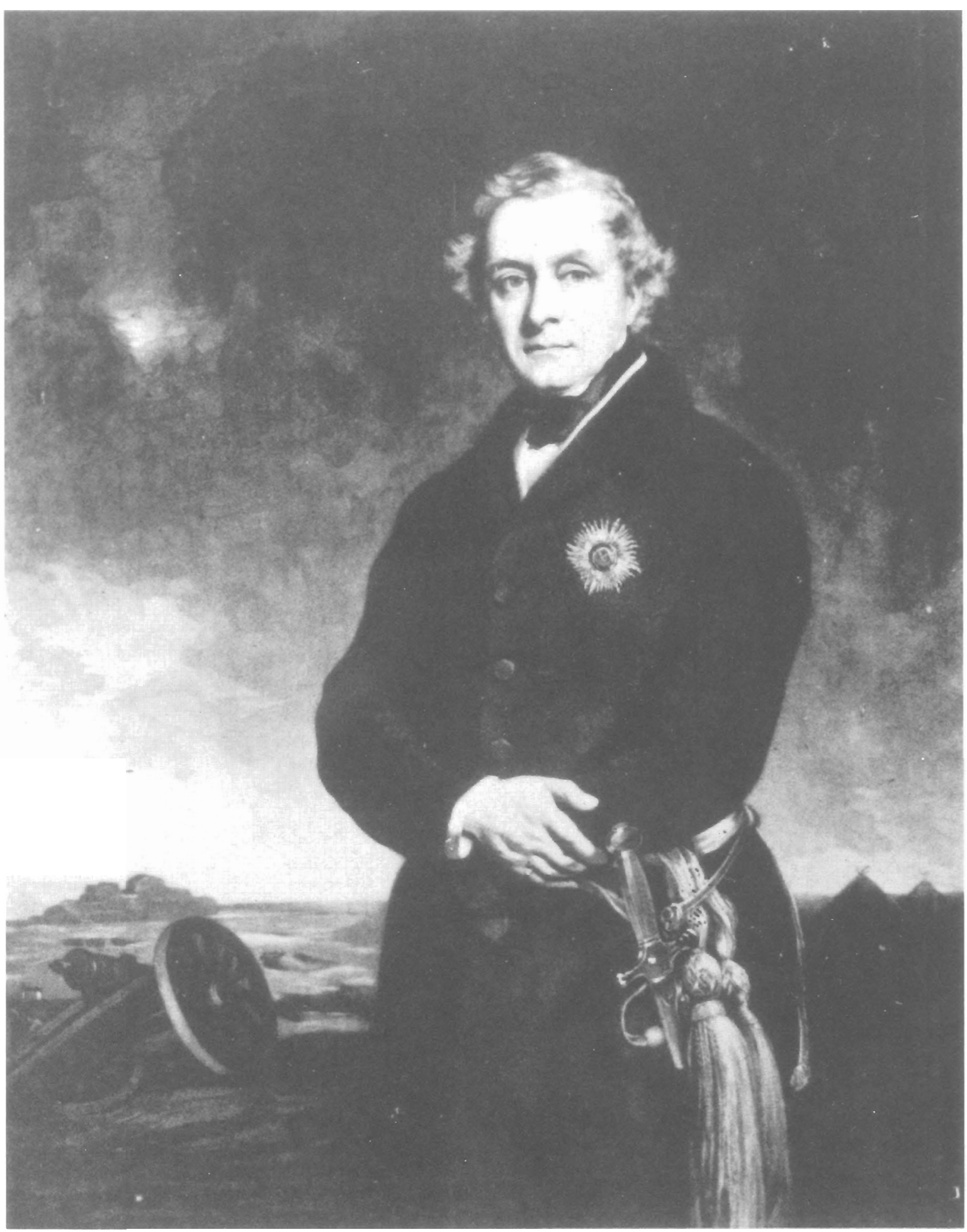

Lord Hardinge wearing the sword Napoleon carried at Waterloo. The sword was given to Hardinge by Wellington. Collotype reproduced from Rulers of India: Viscount Hardinge by his son and private secretary in India, Charles Viscount Hardinge. Oxford, Clarendon Press, 1891 (Frontispiece). 


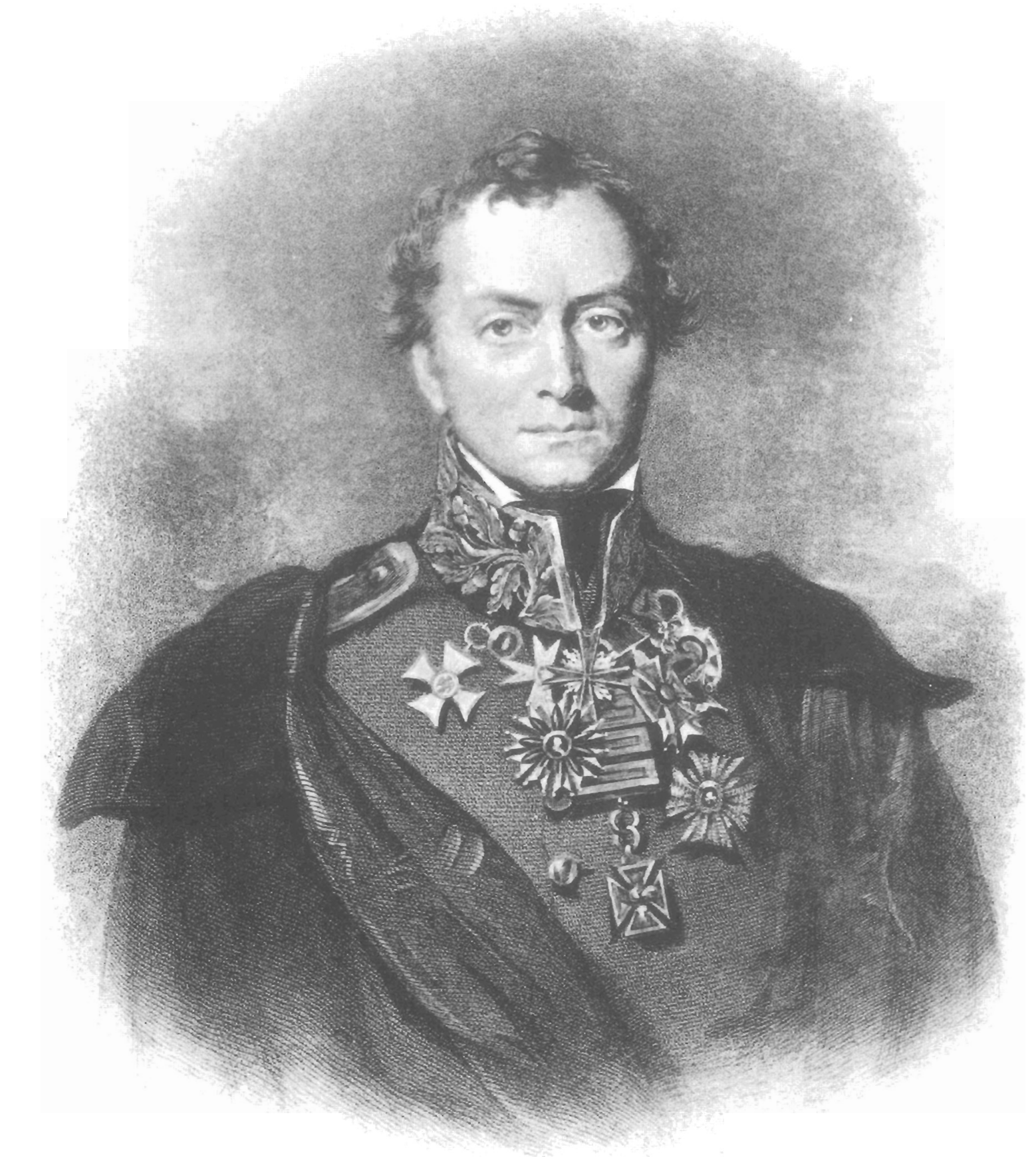

Reproduced from The Life of Wellington: The Restoration of the Martial Power of Great Britain, by Sir Herbert Maxwell. Second Edition. London: Sampson Low, Marston and Co., 1900. v.2, pp. 232-233. 